\title{
Rhipidistians (Sarcopterygii) from the Hunter Siltstone (Late Famennian) near Grenfell, NSW, Australia
}

\author{
Zerina Johanson $^{1}$ \& Alexander Ritchie ${ }^{1}$
}

With 7 figures

\begin{abstract}
Rhipidistian sarcopterygian fishes (Dipnomorpha + Tetrapodomorpha) are well represented in the upper levels of the Hunter Siltstone (latest Famennian) near Grenfell, New South Wales (NSW), Australia. Taxa comprise two porolepiforms (known primarily from scales, including the widely distributed Holoptychius), the basal rhipidistian taxon Grenfellia meemannae n. gen. and n. sp. and two tetrapodomorphs (Eusthenodon gavini n. sp. and Yambira thomsoni n. gen. and n. sp., both known from skull bones and scales). Biogeographic relationships of the Hunter Siltstone fauna are based on the presence of the placoderm group Sinolepidoidei, shared with Late Devonian faunas from the North and South China terranes. Rhipidistian scales have been described from the latter in association with Late Devonian sinolepids (Sinolepis), but these do not display close taxonomic affinity to scales described from Grenfell. Other Upper Devonian NSW localities show strong faunal similarity to Euramerican localities; Holoptychius occurs in certain of these and at Grenfell, but has not been recorded from Sinolepis-bearing units on the North and South China terranes. These considerations further contradict suggestions that Asian terranes acted as a dispersal route between Gondwana and Euramerica in the Late Devonian.
\end{abstract}

Key words: Rhipidistians, Australia, Late Devonian, Famennian, Southeast Asia.

\section{Zusammenfassung}

Rhipidistiide Sarcopterygier (Dipnomorpha + Tetrapodomorpha) sind in den obersten Schichten des Hunter Siltstone (oberstes Famennium) bei Grenfell, New South Wales (NSW), Australien, stark vertreten. Es handelt sich um zwei Porolepiforme (vertreten hauptsächlich als Schuppen, darunter die weit verbreitete Gattung Holoptychius), der primitive Rhipidistier Grenfellia meemannae $\mathrm{n}$. gen. et $\mathrm{n}$. $\mathrm{sp}$. und zwei Tetrapodomorphe (Eusthenodon gavini $\mathrm{n}$. sp. und Yambira thomsoni $\mathrm{n}$. gen. et n. sp., beide vertreten durch Schädelknochen und Schuppen). Biogeographische Beziehungen der Hunter Siltstone-Fauna sind auf der Anwesenheit von sinolepidoiden Placodermen, die in oberdevonischen Faunen der nord- und südchinesischen Terranes auftreten, begründet. Rhipidistier-Schuppen sind zusammen mit oberdevonischen Sinolepiden (Sinolepis) von den chinesischen Terranes beschrieben worden, aber diese zeigen keine nahe taxonomische Übereinstimmung mit den Schuppen von Grenfell. Andere oberdevonische Lokalitäten von NSW zeigen deutliche Ähnlichkeiten in der faunistischen Zusammensetzung mit euramerikanischen Lokalitäten; Holotychius tritt dort und in Grenfell auf, aber ist nicht von Schichten in nordund südchinesischen Terranes, die Sinolepis enthalten, beschrieben worden. Auch diese Vergleiche widersprechen Vorstellungen, dass die asiatischen Terranes im Oberdevon als Verbreitungsweg zwischen Gondwana und Euramerika dienten.

Schlïsselworte: Rhipidistier, Australien, Oberdevon, Famennium, Südost-Asien.

\section{Introduction}

The Grenfell fauna (late Famennian, Young 1999: fig. 5), collected from the upper part of the Hunter Siltstone near Grenfell, NSW (Fig. 1; Ritchie et al. 1992: fig. 2A), preserves the largely disarticulated remains of a variety of fishes. These include acanthodians, a new tooth-plated dipnoan (Johanson \& Ritchie 2000), the arthrodire Groenlandaspis sp. (an unusual form lacking ornament) and the antiarchs Bothriolepis grenfel- lensis Johanson, 1997a, Remigolepis redcliffensis Johanson, 1997a, and Grenfellaspis branagani Ritchie et al., 1992. Relatively common in the fauna are scales and skull bones of tetrapodomorph and porolepiform rhipidistian fishes. Along with the new lungfish, these testify to a diversity of sarcopterygian fishes in the latest Devonian of NSW (Young 1999).

Grenfellaspis branagani belongs to the Sinolepidoidei, a placoderm group known only from NSW and Devonian localities in China and

\footnotetext{
Palaeontology, Australian Museum, 6 College Street, Sydney, NSW 2010, Australia. Received January 2000, accepted May 2000
} 
northern Vietnam (Ritchie et al. 1992. Young 1999). suggesting a biogeographic relationship between these areas. Sinolepids have been described from the Lower Devonian of China, but Grenfellaspis is most closely related to the Famennian genus Sinolepis Liu \& Pan. 1958 (Ritchie et al. 1992), which restricts the time frame of this relationship. Metcalfe (1996) used this information to establish connections between Asian terranes and Australia and to determine timing of rifting of the Asian terranes from Gondwana. However. Young \& Janvier (1999: fig. 1) suggested that these terranes were largely isolated through the Devonian, with some connection to Gondwana occurring in the latest Devonian (based on the sinolepid distribution). To reflect this, they placed an Asian 'superterrane" in the Palaeo-Pacific to the east of Eastern Gondwana.

Two species of Sinolepis have been described from the Wutung Group (in the Nanjing region, South China terrane [Ritchie et al. 1992: fig. 1]). in association with a small number of dipnomorph and tetrapodomorph scales (Pan 1956. 1957a, b, 1964, Liu \& Pan 1958. Wang 1984). Scales from Grenfell include those assigned to the porolepiform taxa Holoptychilus Agassiz in Murchison, 1839, and a new taxon with strongly ornamented scales like those of the 'osteolepids' Litoptychius Denison. 1951 (Schultze \& Chorn 1998) or Glyptopomus Agassiz. 1844 (Jarvik 1950b). Holoptychiid and 'osteolepid' scales have not been described from the Wutung Group, but other porolepiform. dipnoan and tristichopterid scales (Pan 1957b, Liu \& Pan 1958: pl. 9.2) provide points of comparison to those from Grenfell.

In contrast to the Asian links suggested by the distribution of the sinolepid antiarchs, taxa from older (though still Late Devonian) NSW faunas indicate a closer palaeobiogeographic relationship between eastern Australia and European and North American localities. This is shown particularly by the distribution of Holoptychilus, tristichopterid tetrapodomorphs, rhynchodipterid lungfish, tetrapods (Ahlberg et al. in press), and phyllolepid placoderms (Rich \& Young 1996).

It should be noted that marine invertebrates have not been identified in association with these Late Devonian NSW faunas, suggesting a freshwater environment. Nevertheless, identification of Devonian faunas as inhabiting marine or freshwater environments has been controversial (Goujet 1984, Blieck 1985, Mark-Kurik 1991, Blieck \& Janvier 1991, and references therein; Janvier 1996) and somewhat equivocal (Schmitz et al. 1991). Although freshwater fish have been considered important when assessing biogeographic relationships of continental blocks, Young \& Janvier (1999) stressed the distinction between 'continental' and 'oceanic' environments. The former includes freshwater, marginal and shallow marine environments. Fish inhabiting these environments are restricted in their distributions relative to 'oceanic' fishes, and are indicative of continental proximity (marginal and shallow marine) or connection (freshwater).

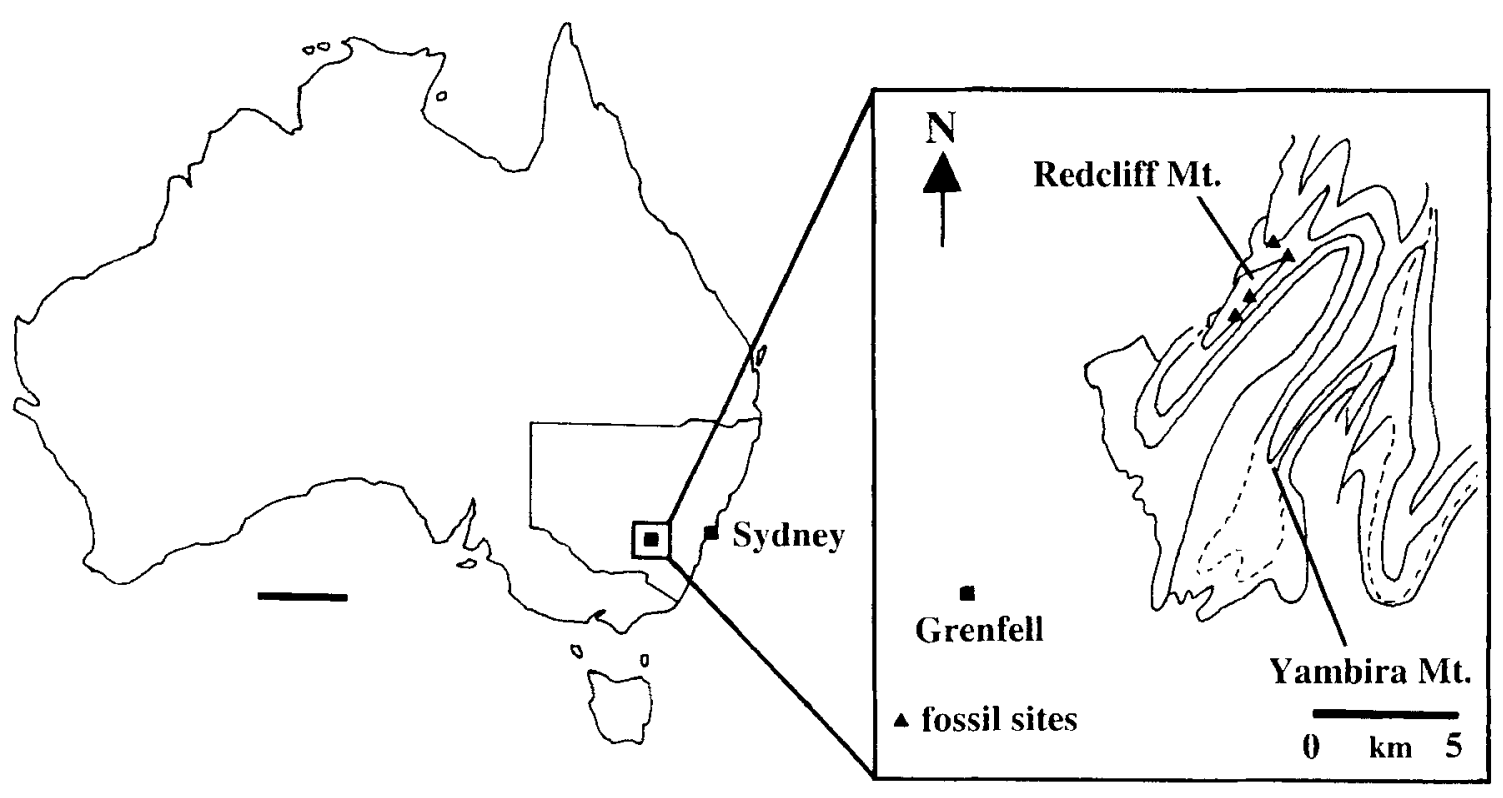

Fig. 1. Location of the Grenfell fauna (Hunter Siltstone. Upper Devonian). Adapled from Ritchie et al. (1992) 


\section{Materials and Methods}

Fossils described below were collected primarily from sites on Redcliff Mountain, although a small amount of material has also been collected from Yambira Mountain (also known as Sugarloaf Mountain) (Fig. 1). Degraded bone was removed in a hydrochloric acid bath to expose natural moulds. Latex casts taken from these were coated with ammonium chloride sublimate for photography and were used for the line drawings. Higher-level classification follows Ahlberg (1991), with the groups Tetrapodomorpha and Dipnomorpha assigned to the Rhipidistia. Within these groups, the following taxa are discussed below: Porolepiformes, Dipnoi (both belonging to the Dipnomorpha), Rhizodontida, Canowindridae, 'Osteolepidae', Megalichthyidae, Tristichopteridae (all Tetrapodomorpha).

Museum abbreviations: AMF - Australian Museum, Sydney; ANU - Australian National University, Canberra; CPC - Commonwealth Palaeontological Collection, Australian Geological Survey Organisation, Canberra; MB.f. - Museum für Naturkunde, Berlin

\section{Systematic Palaeontology}

Sarcopterygii Romer, 1955

Rhipidistia Cope, 1871

Dipnomorpha Ahlberg, 1991

Porolepiformes Jarvik, 1942

Holoptychiidae Owen, 1860

\section{Holoptychius sp.}

Fig. $2 \mathrm{~A}-\mathrm{G}$

Material: AMF56136, AMF56164, AMF56291, AMF78740, AMF78742, AMF78765, AMF78772, AMF79199A, B, AMF79204A, B, AMF107774, AMF107781-4, AMF107794-6, AMF107817-8, AMF107958, AMF107966, AMF107974-5, AMF112198-9, AMF112202, AMF112204-5, AMF112210, AMF113269, AMF113277, CPC35343, CPC35344, all scales.

Occurrence: Upper part of the Hunter Siltstone (Upper Famennian), $15 \mathrm{~km}$ NE of Grenfell, NSW, Australia.

Description: On scales referred to Holoptychius sp. the exposed (non-overlapped) portion is wide, subtriangular, and crossed by long, sinuous ridges of generally uniform thickness. These can merge, especially proximally. A small fan of tubercles is present on certain scales, just anterior to the exposed field of ridges (Fig. 2B-D, F-G). The scales are thick, and overlapped portions are smooth, with no concentric growth rings visible. These scales are similar to others referred to Holoptychius (Agassiz 1844, Woodward 1891, Gross 1966, Jarvik 1980, Cloutier \& Schultze 1996), but there do not appear to be characters adequate to either name a new species or to assign these scales to a known species.
Discussion: A revision of Holoptychius (Brown 1978) indicated that scale ornament was variable throughout ontogeny and at different points along the body. Brown (1978) concluded that the range of scale morphologies represented by several species of Holoptychius would be more appropriately included in a single species. Until this work is published, scales of Holoptychius from the Grenfell fauna are referred to as Holoptychius sp. In NSW, scales of Holoptychius are also known from Late Devonian (Famennian) deposits near Eden and Forbes (Young 1993). They have not been recorded from the Upper Frasnian Mandagery Sandstone (Young 1999) near Canowindra, NSW.

Porolepiformes Jarvik, 1942

Holoptychiidae Owen, 1860

Holoptychiidae n. gen. and n. sp.

Fig. $2 \mathrm{H}-\mathrm{O}$

Synonyms:

1993 a holoptychiid porolepiform. - Young: 236.

1993 porolepiform gen. nov. - Young: 251.

Material: AMF56165-6, AMF78731, AMF107807, AMF107799, AMF107957-8, AMF107961, AMF107968 -9, AMF107978, AMF112200-1, AMF112206, AMF113267-8. all scales.

Remarks: These scales can be assigned to the Holoptychiidae based on the presence of an anterior crescent or fan of small tubercles (usually forming rows) followed by ridges extending to the posterior margin of the scale. Otherwise, their affinities within the Holoptychiidae are uncertain. P. E. Ahlberg (Natural History Museum, London) is currently describing a new holoptychiid from the Givetian (Middle Devonian) of Estonia, including scales closely similar those of Holoptychiidae n. gen. and n. sp. from Grenfell, as well as skull and lower jaw specimens. The Estonian material will form the basis of a new taxon, of which Holoptychiidae n. gen. and n. sp. will likely form a new species. Therefore, taxonomic assignment of the Hunter Siltstone scales is left in open nomenclature, pending Ahlberg's description. One possible porolepiform skull roofing bone is present in the Hunter Siltstone (Fig. 7I, see below), but whether it should assigned to Holoptychius sp. or Holoptychiidae n. gen. and n. sp. is uncertain.

Occurrence: Upper part of the Hunter Siltstone (Upper Famennian), $15 \mathrm{~km}$ NE of Grenfell, NSW, Australia.

Description: Scales of Holoptychiidae n. gen. and $\mathrm{n}$. sp. are thinner than those of Holoptychius 

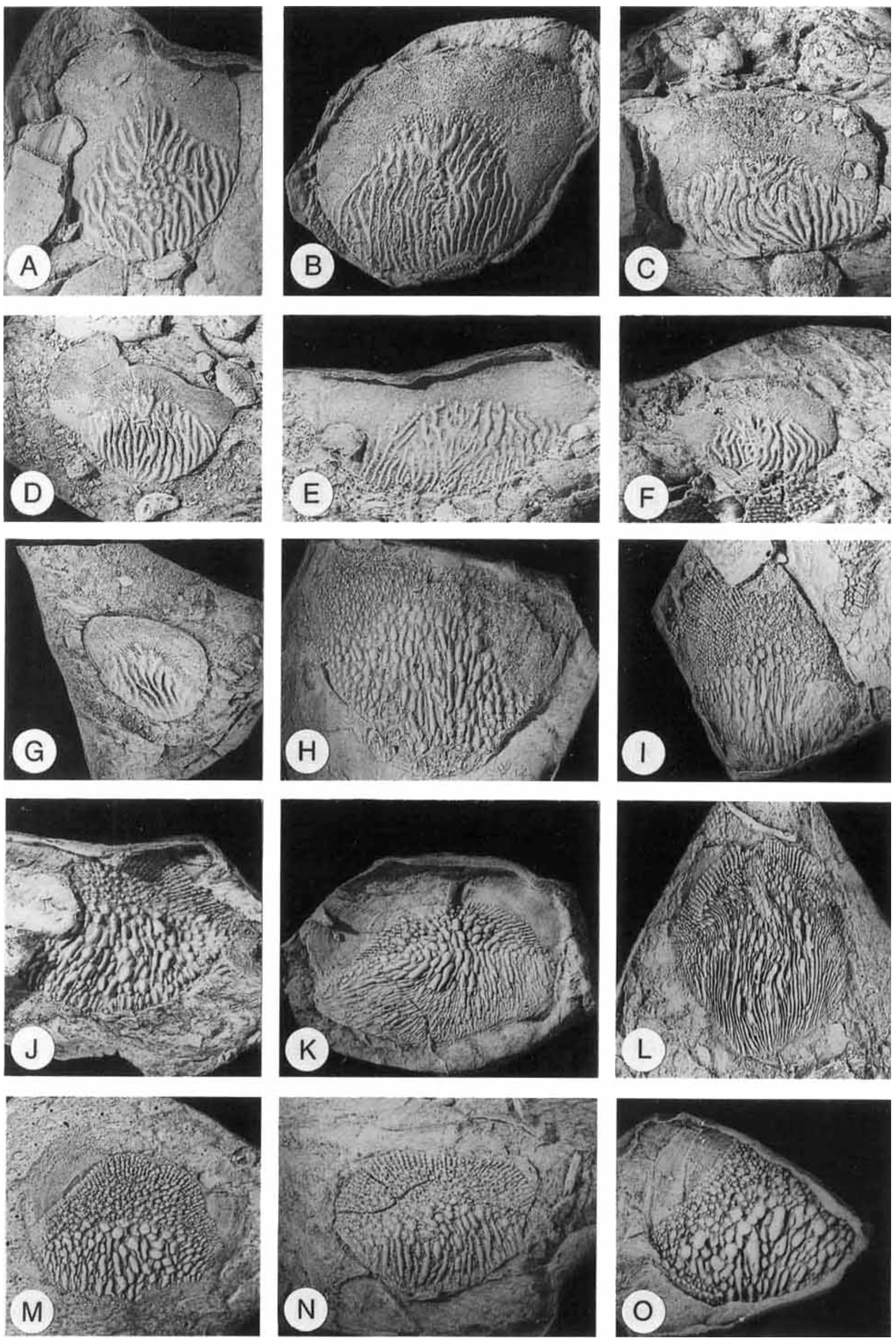
sp. from the Hunter Siltstone, and the overlapped portion is marked by concentric growth lines (Fig. 2K, M, O). The anterior tubercle field consists of a fan of tubercle rows (Fig. 2I-O), followed in some instances by a small area with a more random scattering of tubercles (Fig. 2I, J, $\mathrm{M}-\mathrm{O})$. The shape and width of he anterior tubercle field varies, generally being wide and crescentic in shape (Fig. 2I, J, N), although on other scales, the field can be bell-shaped (Fig. 2M, O), or quite narrow (Fig. 2K). The tubercles overlap one another to some degree, and the crowns carry a teardrop shaped depression, with the point of the drop oriented posteriorly.

Posterior to the anterior tubercle field, the non-overlapped portion of the scale is marked by short, fat, sausage-shaped ridges, particularly in the middle part of the scale. These appear to be rounded on several specimens (Fig. $2 \mathrm{M}-\mathrm{O}$ ), but are larger than the more anterior tubercles, and are considered to be modified ridges. The shorter ridges overlie thinner, more posterior ridges to some degree (Fig. 2J, K, M, O); the latter extend to the edge of the scale.

Discussion: As noted above, relationships of Holoptychiidae $\mathrm{n}$. gen. and $\mathrm{n}$. sp. among described holoptychiids are uncertain. An anterior fan-shaped area of tubercle rows is also present on scales of Laccognathus (Ørvig 1957) and Glyptolepis (Gross 1966), and in other sarcopterygians like Onychodus (Ørvig 1957: fig. 7C). In Holoptychius, the fan of tubercles can be present, but is reduced in width relative to other holoptychiids (Fig. 2B-D; Agassiz 1844, Woodward 1891, Gross 1966, Jarvik 1972, 1980).

Quebecius (Ørvig 1957: fig. 10A, Schultze \& Arsenault 1987) and a scale questionably assigned to Duffichthys (Ahlberg 1992: fig. 6A) lack the anterior rows of tubercles, but possess a scattering of larger tubercles anteriorly. These may be comparable to the larger tubercles described between the anterior fan and the posterior ridge field for Holoptychiidae n. gen. and $\mathrm{n}$. sp. This area of larger, scattered tubercles also occurs in Glyptolepis (Ørvig 1957, Ahlberg 1992) and possibly Laccognathus (Ørvig 1957: fig. 2A), but not Holoptychius (e.g., Fig. 2B-D). Tubercle crowns are marked by a teardrop shaped depres- sion in all the above taxa except Holoptychius (Ørvig 1957).

The ridges on the posterior part of the scales of Holoptychiidae n. gen. and n. $\mathrm{sp}$. are not readily comparable to other described holoptychiid taxa. These short, sausage-like ridges are thickest in the middle of the scale, and become more rounded in some instances (Fig. 2J, $\mathrm{M}-\mathrm{O})$. In Glyptolepis and Quebecius, this part of the scale is crossed by elongate ridges alone (Ørvig 1957), while small tubercles occur among the narrow ridges on the posterior part of the scale of Duffichthys (Ahlberg 1992). In Laccognathus, the field is covered by tubercles of a similar size. Brown (1978) described variability in the ridges and tubercles of this region in Holoptychius, including tubercles fused to ridges. This differs from the condition in Holoptychiidae n. gen. and n. sp., where the rounder ridges occur in the same position on the scale as the sausage-like ridges (compare Fig. $2 \mathrm{M}-\mathrm{O}$ and $2 \mathrm{~K}$ ), and are clearly larger than the tubercles of the anterior fan. As noted above, they are believed to represent modified ridges rather than tubercles.

Scales of a Givetian holoptychiid from Estonia currently being described by $\mathrm{P}$. Ahlberg are most similar to Holoptychiidae $n$. gen. and $n$. sp. in possessing thicker, shorter ridges in the middle of the scale, although these do not appear to be as numerous, or as concentrated in the middle of the scale. It is expected the Hunter Siltstone scales will be a new species of the Estonian genus, although these may prove to fall within the range of scale morphologies in the Estonian form. Most importantly, this association results in a holoptychiid taxon with a considerable age range, otherwise unknown in the Middle and Late Devonian of Australia, and the comparable Antarctic Aztec fauna (Young 1993, 1999, Young et al. 1992). A porolepiform scale was described from the Aztec fauna (Young et al. 1992: fig. $43 \mathrm{C}$ ), but this bears no resemblance to Holoptychiidae n. gen. and n. sp. from Grenfell. ?Glyptolepis was identified from the Mt. Howitt fauna (Victoria; Long 1991, Young 1993: 249), but again, a figured scale lacks the short, fat ridges characteristic of Holoptychiidae n. gen. and n. sp.

Fig. 2. A-G, Holoptychius sp. A, AMF107174, $\times 1.0$. B, AMF107784, $\times 1.2$. C, AMF78772, $\times 1.1$. D. AMF79204A. $\times 1.0$. E AMF107781, $\times 1.0$. F, AMF107782, $\times 2.0$. G, AMF56164, all scales in external view. H-O, Holoptychidae n. gen. and n. sp. H. AMF107799, $\times 1.25$. I, AMF107978, $\times 1.0$. J, AMF787311, $\times 1.2 . \mathbf{K}$, AMF56351, $\times 1.2 . \mathbf{L}$, AMF56166, $\times 1.2$. M, AMF112206, $\times 1.0 . \mathbf{N}$, AMF107807, $\times 1.2 . \mathbf{O}$, AMF78741, $\times 1.2$, all scales in external view 
One important distinction between Holoptychizs and other holoptychiids is that the scale ornament of Holoptychius is formed from bone, but from dentine in other taxa (Ørvig 1957. Ahlberg 1992). Unfortunately, scales of Holoptychiidae $n$. gen. and n. sp. are known only from natural moulds so that composition of the ornament cannot be determined.

Interestingly, scales of Holoptychiidae n. gen. and $\mathrm{n}$. sp. are similar to certain scales ('anteroventral scales') assigned to the coelacanth $\mathrm{Mi}$ guashaia Schultze. 1973 (Cloutier 1996: fig. 17A. B). Coelacanths are poorly known in the Devonian of NSW and Australia as a whole (Young 1993). being described from the Middle and Upper Devonian sites of Mount Howitt (Victoria) and near Pambula in NSW (Long 1999). Coelacanth scales generally differ from those in Fig. 2 (e.g. Woodward 1891: pl. 14. Forey 1981), although a scale assigned to ?Diplocercides jarviki Stensiö. 1922 (Jarvik 1950b: fig. 33F) also possesses the thicker ridges to some degree.

However, referral of the Grenfell scales to $\mathrm{Mi}$ guashaia is not supported. Other scales assigned to Miguashaia (Cloutier 1996: fig. 17B, C, E) show an ornament of densely packed, elongate. narrow ridges that do not overlap; this other morphology has not been observed on any Hunter Siltstone scale. Additionally, there is no strong indication of coelacanth skull bones in the Hunter Siltstone (based on comparable ornament, e.g.. Forey 1981). As noted above. Holoptychiidae n. gen. and n. sp. scales appear most similar to scales from Estonia, which occur with undoubted holoptychiid skull and lower jaw specimens. A referral to the Porolepiformes and the Holoptychiidae seems most appropriate at this time.

Almost all skull bones from the Hunter Siltstone described in this work are assigned to new tetrapodomorph taxa rather than associated with the porolepiform (holoptychiid) scales described above. For example, three postparietals are identified; certain of these possess pitlines (Fig. 5E) or corresponding growth centers (Fig. 5G) in the posterior half of the bone. In porolepiforms. these growth centres are more anteriorly positioned and the postparietal and supratemporal bones are fused (e.g. Jarvik 1972). However, in Fig. 5D. E, the postparietal is narrow anteriorly, with a distinct overlap for a separate supratemporal bone (oa.St. Fig. 6C). Additionally, a lateral extrascapular (Fig. 5C) lacks an overlap area for the median extrascapular. which again is contrary to the porolepiform condition (Jarvik
1980). A partial maxilla shows a portion of the anterior dorsal process marking the posterior margin of the choana (dp, Figs $5 \mathrm{~A}, 6 \mathrm{~A}, \mathrm{~B}$ ); as well, the maxilla narrows internally just posterior to the dorsal process (Fig. 5B). These conditions are not seen on maxillae of Holoptychius (Jarvik 1972: pl. 33). Rostral or nasal bones are present in the Hunter Siltstone fauna (Fig. 7F, L-N), and could be assigned to Holoptychius, which is characterised by a mosaic of small bones in the snout region (Jarvik 1972). However, these rostral/nasal bones have dermal ornament matching other definite tetrapodomorph bones (Fig. 7A-C), and are instead associated with these.

One partial skull roof specimen possesses distinct porolepiform characteristics. This is AMF107970 (Fig. 7I), preserving elongate bones in internal view. These are interpreted as a pair of postparietals (the left poorly preserved), separated by a straight, elongate suture. The bone on the right side of the skull is complete anteriorly (top of figure), and is crossed by a strongly curved line (Fig. 7I, large arrow to the left) that passes through the growth centre of the bone (Fig. 7I, smaller arrow to the right). This growth centre is located closer to the anterior margin than the posterior. Radiating lines from the growth centre extend to all parts of the bone. On porolepiform postparietal shields (Jarvik 1972, 1980), the postparietal bone is fused with the more anterolateral supratemporal, and the growth centre is shifted anteriorly. The infraorbital sensory canal runs from the parietal shield, through this growth centre and then curves laterally to continue onto the tabular bone (Jarvik 1972: fig. 38, pl. 33.6). This is comparable to the morphology described for AMF107970.

Among tetrapodomorph sarcopterygians, the postparietal growth centre is located in the posterior half of the postparietal (Fig. 5G; Jarvik 1980, Young et al. 1992: fig. 7, Fox et al. 1995: fig. 9. Long et al. 1997: fig. 11F, G), and the infraorbital sensory canal runs through the bones lateral to the postparietal (supratemporal and tabular).

An exception to this is seen in derived rhizodonts such as Strepsodus anculonamensis Andrews, 1985, Screbodinus ornatus (Andrews, 1985) and Rhizodus hibberti Owen, 1840 (all Andrews 1985: fig. 7). where the growth centre of the postparietal is relatively anterior and the infraorbital canal is deflected from its course along the (unfused) supratemporal to this growth center. Thus, on these derived rhizodonts the infra- 
orbital canal crosses onto the postparietal anterolaterally, while on AMF107970, the canal crosses onto the postparietal anteriorly, as it does in porolepiforms (Jarvik 1972: fig. 38).

Finally, the morphology of this skull roofing bone is not comparable to coelacanths like $\mathrm{Mi}$ guashaia; here the supratemporal and tabular bones are not fused to the postparietal, and the infraorbital canal runs along these rather than across the postparietal growth center (Cloutier 1996: figs 2-4). Thus, AMF107970 represents the left postparietal and right postparietal-supratemporal bones of a holoptychiid porolepiform (based on scales described above). Because two holoptychiid taxa are present, AMF107970 cannot be assigned further at this time.

\section{Sarcopterygii Romer, 1955 \\ Rhipidistia Cope, 1871 \\ Grenfellia n. gen.}

Diagnosis: As for type and only known species.

Etymology: After the town of Grenfell, NSW, Australia.

\section{Grenfellia meemannae n. sp.}

Figs $3 \mathrm{~A}-\mathrm{E}, 4$

Holotype and only specimen: AMF63891A, B, part and counterpart of a right cleithrum, preserving part of the internal and external surfaces.

Diagnosis: A rhipidistian sarcopterygian based on presence of a tripodal scapulocoracoid walled laterally by the cleithrum (rather than an extension of the scapulocoracoid); differs from all other rhipidistian and sarcopterygian taxa in possessing a coarse dermal ornament of medium-sized tubercles, the base of each surrounded by radiating foramina.

Etymology: After Chang Meemann (Beijing) for her contribution to the study of Palaeozoic fishes, including the basal dipnomorph Youngolepis.

Occurrence: Upper part of the Hunter Siltstone (Upper Famennian), $15 \mathrm{~km} \mathrm{NE}$ of Grenfell, New South Wales, Australia.

Description: Specimen AMF63891A, B (Figs $3 \mathrm{~A}-\mathrm{E}, 4)$ is identified as a cleithrum based on the morphology of the internal surface (Fig. 3A, B). Here, two separate, flattened, lobate triangular structures are present, equal in size and forming a triangle with a third, fainter area of roughened bone. This third area is also separate and does not merge with the other two structures in any way.

Semicircular areas of unfinished bone (arrow, Fig. 4) along the proximal edges of the two lobate structures are suggestive of areas of attachment, as is the roughened posterior area. The relative position of these, their separation on the internal surface, and their identification as attachment areas most closely matches the morphology of the tripodal scapulocoracoid present in the Tetrapodomorpha and several lungfishes (Dipnomorpha). Here, the main body of the scapulocoracoid is supported on (above) the cleithrum by three buttresses. The buttresses themselves are separated by foramina of varying sizes which are interconnected beneath the scapulocoracoid. Thus, AMF63891A, B is a cleithrum preserving the internal surface with scapulocoracoid attachments (and other features described below), as well as a smaller portion of the external tuberculated surface (Fig. 3C-E).

The orientation of this cleithrum can be determined by the position of the scapulocoracoid attachments. These must be posteriorly placed to allow for attachment of the endoskeletal bones of the pectoral fin. The dorsal and ventral margins are determined by the curvature of the cleithrum, resulting in the orientation presented in Figure 3A, B. Thus, the more dorsal of the scapulocoracoid attachment surfaces (sc.d, Fig. 4) is positioned approximately where the ventral lamina begins to curve and meets the dorsal lamina of the cleithrum. The second attachment (sc.a) is anteroventral to the first, on the ventral lamina of the cleithrum. The third attachment (sc.p, the rough, circular patch) occurs at the posterior margin of the cleithrum, supporting the glenoid fossa of the scapulocoracoid. All three attachments are of roughly similar size. The open area between these attachments indicates that these three foramina were interconnecting.

The size of the foramina separating the three buttresses of the scapulocoracoid (supraglenoid, supracoracoid and subscapular; f.sgl, f.spc, ssf, Fig. 4) can be estimated by the separation of the attachments; it appears that the supraglenoid and subscapular fossae are small and approximately the same size, while the more posteroventral supracoracoid fossa is about twice as large.

A distinct but narrow overlap surface (oa.scale) extends along the ventromedial margin of the cleithrum, narrowing posteriorly. This overlap surface is morphologically similar to that said to overlap scales on the cleithra of porolepi- 

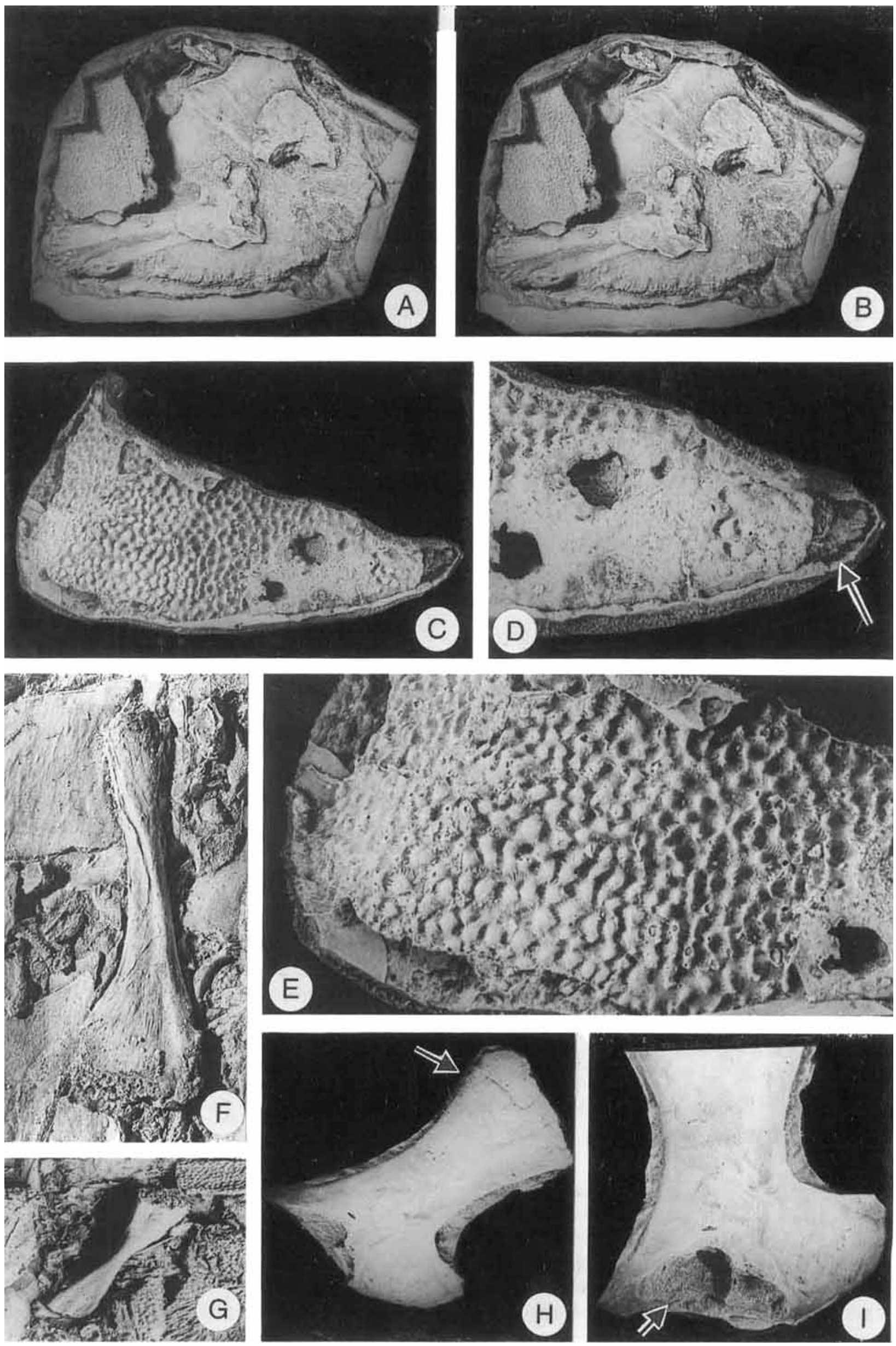
forms (Jarvik 1972: fig. 51G, pl. 13.5), Youngolepis (Chang 1991: fig. 13, pl. 6E) and 'Osteolepid $A^{\prime}$ (Janvier 1980: fig. 2A), and is identified as such.

By comparing the internal and external counterpart surfaces and the extent of the undamaged (or true) margins of AMF63891A, B (Fig. 3A-C), it appears that a large part of the internal surface of the cleithrum is represented, although much of the dorsal lamina is missing (Fig. 4, dotted line). The cleithrum of Grenfellia is anteroposteriorly broad at the level of the dorsal scapulocoracoid attachment so that at least one-third of the width of the cleithrum occurs anterior to this attachment. Additionally, the anteroventral corner of the cleithrum is lengthened or extended beyond the anterior scapulocoracoid attachment.

An unusual feature of the cleithrum is the elongate ridge $(r)$ extending from the anterior scapulocoracoid attachment to the anteromedial edge of the ventral lamina, where it is approximately $4-5 \mathrm{~mm}$ thick. It is narrow near the attachment, and flares anteriorly. The ridge sits on, but is not part of, the main body of the cleithrum, so by itself does not represent the anterior extension of the anteroventral edge of the cleithrum. By again matching the position of the anterior margins of the internal and external surfaces on AMF63891 A, B, it is apparent that this flared portion of the internal ridge extends beyond the (true) edge of the external surface by about 6 or $7 \mathrm{~mm}$ (Fig. 3D, arrow). This extension forms the anteromedial corner of the ventral lamina of the cleithrum.

It is difficult to reconstruct overlap relationships between a clavicle (not preserved) and the cleithrum of Grenfellia, given the thickness of the ridge just described and difficulties in interpreting the margins of the cleithrum dorsal to this ridge (being incomplete externally, and overlain by an antiarch plate internally). This is discussed in more detail below.

The preserved external surface of the cleithrum is covered in its entirety by a tuberculate ornament (Fig. 3C-E). The tubercles are moderately large, and of equal size with narrow forami- na radiating outwards from the base of the tubercle (Fig. 3E). Two larger holes in the external surface are visible near the anterior part of the cleithrum (Fig. 3C, D). These are believed to be pathological in nature, and have resulted in a modification of nearby ornament. It is difficult to be more specific as to the cause of this pathology.

Discussion: The tuberculate ornament covering the external surface of the cleithrum of Grenfellia meemannae is somewhat similar to the ornament on the skull bones of the 'osteolepid' Yambira n. gen. described below (Fig. 7). These skull bones are associated with scales possessing a similar ornament (Fig. 7E, G, H, K), also seen in 'osteolepid' taxa such as Litoptychius (Schultze \& Chorn 1998), Glyptopomus (Jarvik 1950b), and the elpistostegid Panderichthys (Gross 1933a: fig. 6.5, 1966: fig. 6D, Vorobyeva \& Schultze 1991). However, the tuberculate ornament present in Grenfellia differs from the ornament of Yambira n. gen. in possessing elongate canals or foramina radiating outwards from the base of each tubercle (compare Fig. 3E with Fig. 7D). This resembles the tubercle morphology seen in various Placodermi (Karatajūté-Talimaa 1963: pl. 22, Miles \& Westoll 1968: pl.X, Dennis \& Miles 1981: fig. 8A, Ritchie et al. 1992), and is not known to occur in any other sarcopterygian. Small pores are found on external surface of various cleithra assigned to the Rhizodontida (e.g., Gooloogongia loomesi Johanson \& Ahlberg, 1998), but these are not associated with large tubercles.

The Placodermi is generally considered to be a phylogenetically basal taxon within the Gnathostomata (Janvier 1996), such that the appearance of this tubercle morphology in Grenfellia would be the result of convergence (a histological study would be needed to confirm the homology of the ornament in these taxa [e.g., the presence of semidentine]; unfortunately, Grenfellia is known only from a natural mold). The morphology of the Grenfellia ornament is suggested to be an autapomorphy, and supports the naming of a new genus for AMF63891A, B.

Fig. 3. A-E, Grenfellia meemannae n. gen. and n. sp. A, B, AMF63891B, stereopair of cleithrum in internal view, $\times 0.65$. C. AMF63891A, ventral portion of cleithrum in external view, $\times 0.72$. D, AMF63891A, closeup of anteroventral portion of cleithrum, arrow showing extension of internal ridge beyond the margin of the cleithrum, $\times 1.3$. E, AMF63891 A, closeup of external surface showing morphology of tubercles, $\times 1.8$. F-I, Tetrapodomorph postcranial elements. F, AMF107797A, large unpaired fin radial, $\times 0.94$. G, AMF112209, radial of pectoral fin, $\times 1.3$. H, I, AMF107453, anal fin support $(\times 1.04, \times 1.75$, respectively), arrow in Fig. $3 \mathrm{H}$ indicates proximal part of fin support; arrow in Fig. 3I indicates posterior radial articulation surface 


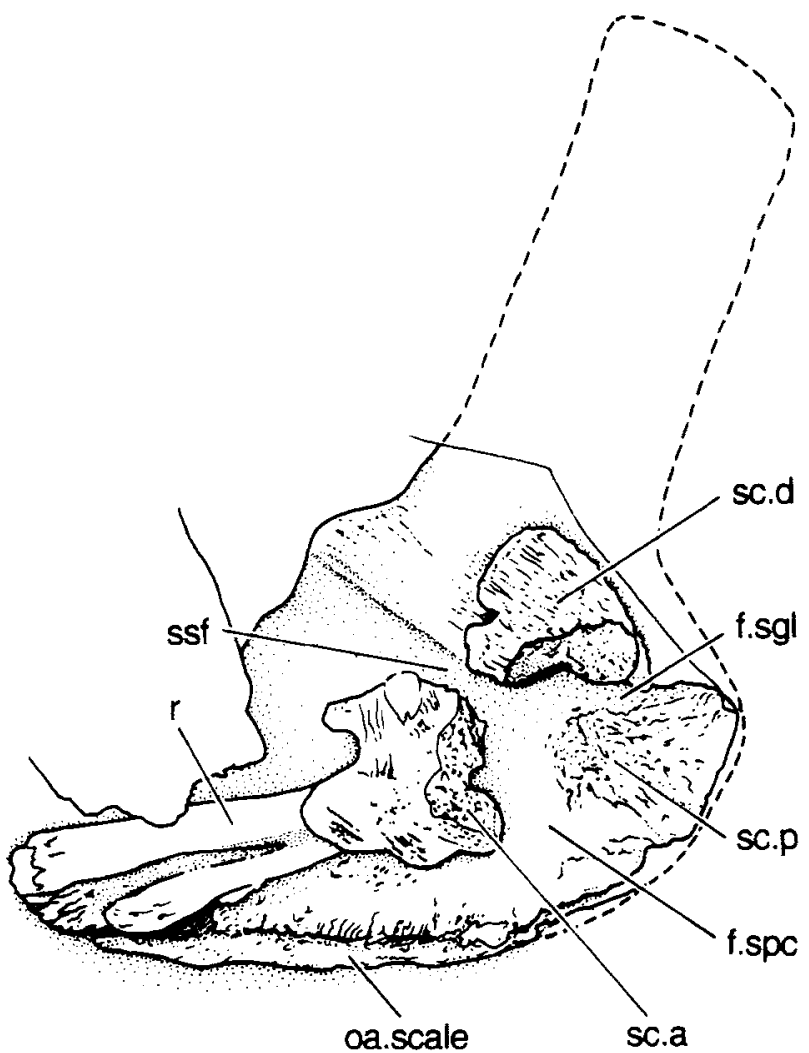

Fig. 4. Grenfellia meemannae n. gen. and n. sp. AMF63891B, cleithrum in internal view. arrow marks area of unfinished bone (reconstruction of posterior margin and dorsal lamina marked by dotted line). f.sgl. glenoid fossa: f.spc. supracoracoid foramen: oa.scale. edge overlapping scales: r. ridge on internal surface of cleithrum: sc.a. anterior scapulocoracoid attachment; sc.d, dorsal scapulocoracoid attachment: sc.p. posterior scapulocoracoid attachment: ssf. subscapular fossa

Certain features of the cleithrum of Grenfellia support a referral to the Rhipidistia, but resolving relationships of Grenfellia within this group is not possible based on current evidence, as these characters occur both in the Dipnomorpha and Tetrapodomorpha.

For example, the tripodal scapulocoracoid supported by three distinct buttresses present in Grenfellia is characteristic of all known basal Tetrapodomorpha (e.g., Andrews \& Westoll 1970a, Long 1985a: fig. 11, Jarvik 1980, Lebedev 1995, Fox et al. 1995). These buttresses are separated by interconnecting foramina. However, this morphology also occurs in various dipnomorph taxa including (possibly) Youngolepis Chang \& Yu, 1981, but more clearly in the lungfish Griphognathus Gross. 1956, Uranolophus Denison. 1968, Chirodipterus Gross. 1933b (Janvier 1980. 1996, Campbell \& Barwick 1987. 1999) and Pillararhynchus Campbell \& Barwick, 1990 (Barwick \& Campbell 1996).

The posterior buttress for the glenoid fossa is relatively very small (Long, pers. comm. 1999) in the lungfish Pillararhychus (Barwick \& Campbell 1996: pl. 8.3A, B), Chirodipterus and Griphognathus (Campbell \& Barwick 1999: figs 21D, 22A). This may be a unique character for the Dipnoi relative to the similar buttress size in many tetrapodomorphs (Long, pers. comm. 1999, e.g., Lebedev 1995). Nevertheless, the buttresses appear to be more similar in size in the lungfish Uranolophus (Campbell \& Barwick 1988: fig. 24), and a very small posterior buttress may be present in Youngolepis (Chang 1991: fig. 16) and in 'Osteolepid A' (Janvier 1980). Among tetrapodomorphs, the posterior buttress of Eusthenopteron Whiteaves, 1881 (Andrews \& Westoll 1970a) is a different shape and size from the more anterior buttresses, while in Cabonnichthys Ahlberg \& Johanson, 1997 (Ahlberg \& Johanson 1997: figs 12, 13), the anteroventral buttress is distinctly the smallest. The buttresses of the megalichthyid tetrapodomorphs also show a variety of sizes and shapes (Thomson \& Rackoff 1974. Fox et al. 1995: fig. 63). It may be difficult to draw reliable phylogenetic conclusions from such variable data.

The morphology of the scapulocoracoid of the dipnomorph Youngolepis (Chang 1991: pl. 6E) is somewhat difficult to interpret. It appears that three distinct buttresses are present (although the relative position of the anterior two buttresses is unusual, and differs from the above taxa, and Grenfellia). Two foramina are also visible (subscapular anteriorly and supracoracoid posteroventrally). It is difficult to establish whether these foramina were interconnecting, and in fact, the central portion of the scapulocoracoid body appears attached to the cleithrum. Dipnomorphs such as the porolepiform Glyptolepis (Ahlberg 1989) possess a triradiate scapulocoracoid where the 'buttresses' are not separated by interconnected foramina, and most or all of the scapulocoracoid appears firmly attached to the cleithrum surface. Other dipnomorph taxa (e.g., the porolepiforms Porolepis [Jarvik 1972: pl. 13.5] and Holoptychius [Jarvik 1972: fig. 52F]) possess a flattened, elongate scapulocoracoid, lacking any indication of discrete buttresses or foramina.

The tripodal scapulocoracoid may have a wider distribution within the Osteichthyes. Gardiner (1984: 380) suggested that this morphology and the presence of a supraglenoid foramen were synapomorphies of the Osteichthyes, being present in phylogenetically basal actinopterygians like Mimia Gardiner \& Bartram, 1977. A supracoracoid foramen may also be present in 
Mimia (Janvier 1996: fig. 4.66, 25). However, as Janvier (1980) noted, foramina associated with the actinopterygian scapulocoracoid were walled laterally by a plate-like extension of the scapulocoracoid (the 'processus lateralis'), whereas in the Rhipidistia, this structure is absent and the foramina were walled by the dermal bone of the cleithrum. This could be considered a synapomorphy of the Rhipidistia. As well, the foramina in Mimia are separate and not interconnected below the scapulocoracoid (Gardiner 1984: figs 128, 129).

It is more difficult to assess the condition in the porolepiforms and Youngolepis, as the lateral face of the scapulocoracoid in these taxa, attached directly to the cleithrum, may be homologous to the 'processus lateralis' (Janvier 1980). Alternatively, the absence of distinct, interconnected foramina in these taxa may be considered derived within the Rhipidistia.

The cleithrum of Grenfellia possesses an extension or elongation of the anteroventral lamina of the cleithrum, well beyond the anterior scapulocoracoid attachment. Among the Dipnomorpha, this is seen in porolepiforms, Youngolepis, Powichthys Jessen, 1975 and possibly the lungfish Uranolophus (Jarvik 1972, Jessen 1980, Campbell \& Barwick 1988, Chang 1991). The elongate surface along the ventromedial margin overlapping scales is also seen in porolepiforms and Youngolepis (but less so in Powichthys). However, both these states occur on a cleithrum referred to as 'Osteolepid A' from the Emsian or Eifelian of Iran (Janvier 1980). Skull material associated with this cleithrum and assigned to 'Osteolepid A' supports a referral to the Tetrapodomorpha (Janvier 1980: fig. 3).

Thus, it appears that the anteroventral extension and the elongate overlap area along the ventromedial margin of the cleithrum are also general rhipidistian characters, occurring in both dipnomorph (porolepiforms, Youngolepis and Powichthys) and tetrapodomorph ('Osteolepid A') taxa. These characters (along with the tripodal scapulocoracoid) therefore can only justify the assignment of Grenfellia to the Rhipidistia.

Other characters of Grenfellia appear to be plesiomorphic for the Rhipidistia. The cleithrum of Grenfellia is wider anteriorly, at or just above the level of the dorsal scapulocoracoid attachment. By comparison, the sarcopterygian cleithrum is generally narrower throughout (Jarvik 1980, Long 1985a, Cloutier 1996), although this wider cleithrum also occurs in Youngolepis, Powichthys and Psarolepis Yu, 1998
(Zhu et al. 1999). The latter has most recently been resolved as a basal sarcopterygian or perhaps even a basal osteichthyan (Zhu et al. 1999), therefore, the greater dorsal width of the cleithrum is likely a plesiomorphic state for the Rhipidistia.

One other character to be discussed is the elongate ridge running forward from the anterior scapulocoracoid attachment in Grenfellia. A much lower ridge in this position is present in the dipnomorph Glyptolepis baltica (Jarvik 1972: fig. 53G) and in tetrapodomorphs like 'Osteolepid A' (Janvier 1980: fig. 1). In Grenfellia, this ridge extends beyond the anteroventral margin of the cleithrum to be visible in external view. A similar structure is observed in the lungfish Uranolophus (Campbell \& Barwick 1988), but in this taxon is flatter and broader, and more flange-like in appearance. In Uranolophus, the flange inserts into a corresponding slot on the clavicle. The clavicle is not preserved for Grenfellia, but as noted earlier, the ridge in Grenfellia becomes thicker anteriorly $(4-5 \mathrm{~mm})$, and may not have inserted into a clavicle slot as readily. As well, the flange of Uranolophus does not appear to be as separate from the main body of the cleithrum as does the ridge in Grenfellia. Indeed, the flange in Uranolophus may represent the anterior extension of the anteroventral portion of the cleithrum. It is believed these structures in Grenfellia and Uranolophus are nonhomologous and not indicative of a sister group relationship between the two. The presence of the ridge in Grenfellia could be another autapomorphy for this taxon.

The presence of the general rhipidistian characters described above, and the greater dorsal width of the cleithrum of Grenfellia (seen in Youngolepis, Powichthys and Psarolepis and likely plesiomorphic for the Rhipidistia) indicate that Grenfellia may occupy a basal phylogenetic position within the Rhipidistia. Grenfellia differs from all other rhipidistians and sarcopterygians in the presence of a tuberculate ornament on the cleithrum resembling the placoderm condition. In other sarcopterygians, cleithral ornament is more usually reticulate (Andrews \& Westoll 1970a, Jarvik 1972: pls 13, 34, 1980, Campbell \& Barwick 1988: fig. 23E, 1997, Lebedev 1995, Fox et al. 1995). Interestingly, this more typical ornamentation is also absent from the cleithrum of Psarolepis, which is instead covered by an ornament of fine pores (Zhu et al. 1999). 
Tetrapodomorpha Ahlberg, 1991

Family Tristichopteridae Cope. 1889

Eusthenodon Jarvik, 1952

Eusthenodon gavini n. sp.

Figs $5 \mathrm{~A}-\mathrm{L}, 6 \mathrm{~A}-\mathrm{C}, \mathrm{E}$

Synonyms:

1993 ? Eusthenodon sp. - Young: 251.

Holoty pe: AMF56289. 56290 . part and counterpart of partial maxilla (Fig. 5A. B).

Paratypes: AMF78760. 107772. 107778. left internal and right external postparietals, respectively: AMF107776, right lateral extrascapular: AMFI07789. quadratojugal: AMF56167. AMF61416A. B. AMF78139. AMF78752A. B. AMF107793. AMF107811. AMF107815. AMF107956. AMF107811. AMF107819. AMF107962. AMF107963-5. AMF107967. AMF107971. AMF107976A. B. AMF107977. AMF112192-4. AMF112203. AMF112207-8. AMF112211. AMF113276. AMF115264-5. CPC 35345-35349. MB. f.7576. all scales.

Diagnosis: Differs from Eusthenodon wängsjöi in possessing scales showing a triangular ornamented field composed of grooves (often anastomosing).

Remarks: Material described below is assigned to Eusthenodon among the Tristichopteridae based on the coarse ornamentation of the skull bones and in possessing a more transverse quadratojugal-preopercular margin (resulting in a broader preopercular bone).

Etymology: After Gavin Young. Canberra. for his studies on Devonian fishes and more specifically his work in the Grenfell region.

Occurrence: Upper part of the Hunter Siltstone (Upper Famennian). $15 \mathrm{~km}$ NE of Grenfell. New South Wales, Australia.

Description: All skull bones and scales assigned to Eusthenodon gavini n. sp. are disarticulated, and some are damaged (Fig. 5A, B. G). Cosmine is absent and the skull bones possess a well-developed, strongly reticulate ornament. Bones referred to the second new tetrapodomorph taxon below possess a more tuberculate ornament (Fig. 7). Pitlines are present on some of the bones, but lateral line canals have not been observed.

Maxilla: The holotype (AMF56289. AMF56290. part and counterpart) is a partial left maxilla preserving internal and external surfaces (Figs 5A, B, $6 \mathrm{~A}, \mathrm{~B})$. Two concave overlap surfaces are visible in external view, separated by a low but sharply pointed rise in the ornamented surface of the maxilla. This sharp rise separates overlap areas for the lacrimal anteriorly and the jugal posteriorly (oa.La, oa.Ju, Fig. 6A). The maxilla is broken halfway through the overlap for the jugal.

The anteriormost part of the maxilla is also missing. A dorsal process issuing from the anterior extremity of the maxilla has been described in several tetrapodomorph taxa (Fox et al. 1995, Lebedev 1995. Long et al. 1997). This process, visible in both external and internal view, is marked by a deep notch and serves as the posterior margin for the choana, and also as a buttress against the dermopalatine (Long et al. 1997). Internally, this process issues from a strong ridge just above the tooth row, beginning at the narrowest part of the maxilla and widening anteriorly to the deep notch. The morphology of AMF56289 is similar, with a narrowing of the maxilla clearly visible internally (n, Fig. 6B), as is a ridge above the tooth row, widening anteriorly (dp, Fig. 6B). This can also be seen in external view (dp, Fig. 6A), indicating the presence of the posterior part of the dorsal process of the maxilla (and by inference the notch forming the posterior margin of the choana) in Eusthenodon gavini.

Thus, the maxilla is nearly complete anteriorly, as is the overlap area for the lacrimal bone. The lacrimal appears to be a long bone, but if the overlap for the jugal behind it is approximately half complete, then a reconstructed jugal would be nearly as long as the lacrimal (based on the curvature of the preserved portion of the jugal; the overlap appears to be reaching its maximum depth at the broken edge of the preserved maxilla). The overlap for the jugal is only slightly deeper than that for the lacrimal, suggesting that any increase in the height of the maxilla would be restricted to its posterior portion.

The teeth along the margin of the maxilla are best preserved in internal view (Fig. 5B), where they are stout and striated. The internal structure of the teeth cannot be investigated, due to their preservation as natural moulds.

Postparietal: Three postparietals are assigned to Eusthenodon gavini (Fig. 5D, E, G), in-

Fig. 5. A-L. Fusthenodon gavini n. sp. A. B. AMF56290. 56289. part and counterpart of partial left maxilla, internal and cxtcrnal views. $\times 1.0$. C. AMF107776. right lateral cxtrascapular in external view, $\times 1.2$. D, AMF107778, $(\times 1.2)$. E, AMF107772 $(\times 1.2)$. postparietals in external view. F. AMF107789. right quadratojugal in external view, $\times 1.3$. G, AMF78760, postparietal in internal view. arrow indicates overlap for tabular bone. $\times 1.3$. H. I. MB.f. 7576 , scale in external and internal views. $\times 1.4$. J. K. MB.f. 7576, scale in external and internal views. $\times 1.0$. L. AMF56167, scale in external view, $\times 1.5$ 

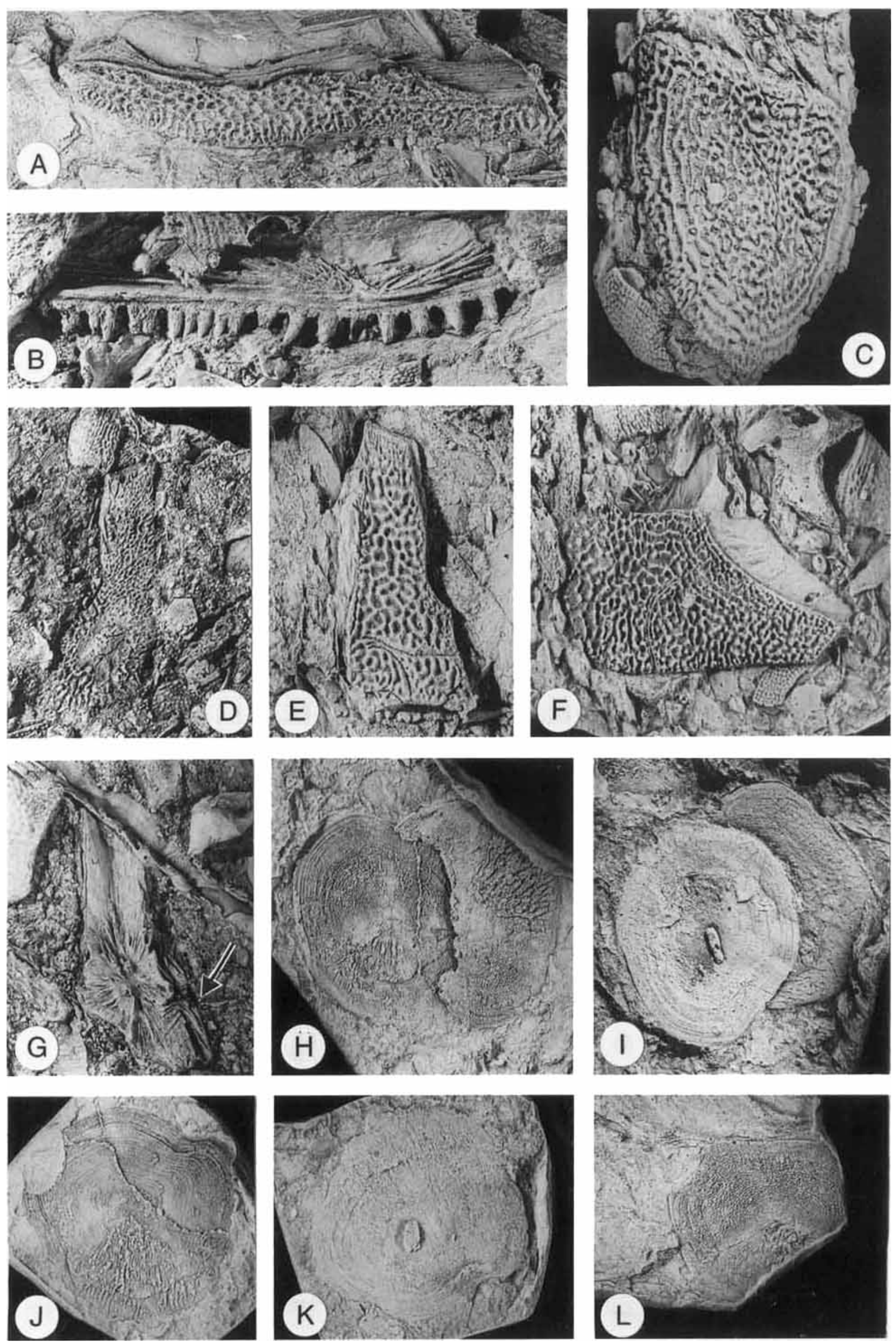
A
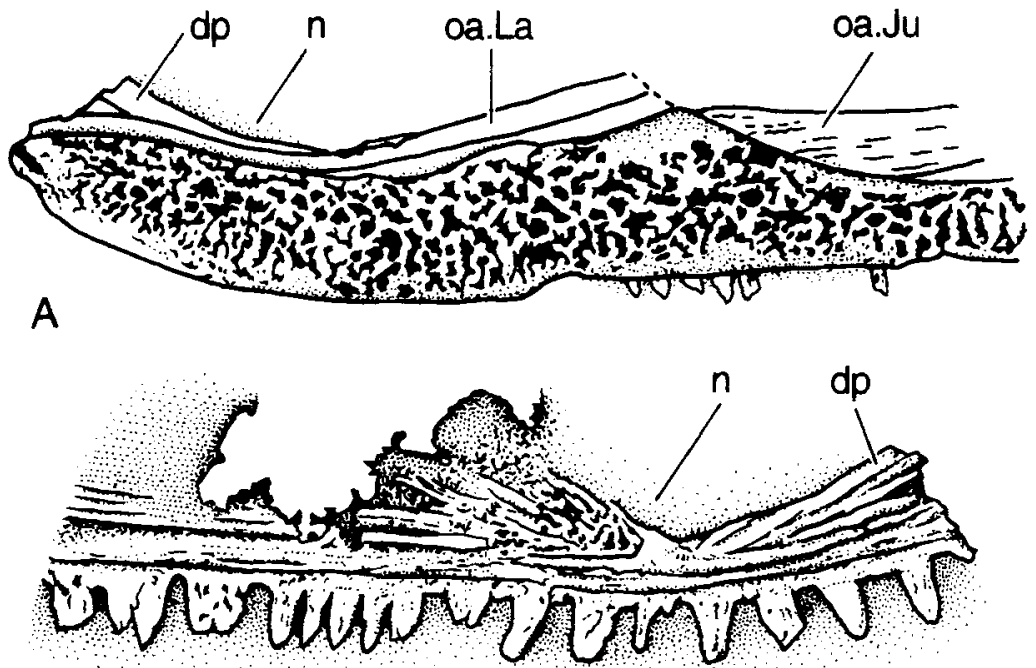

B
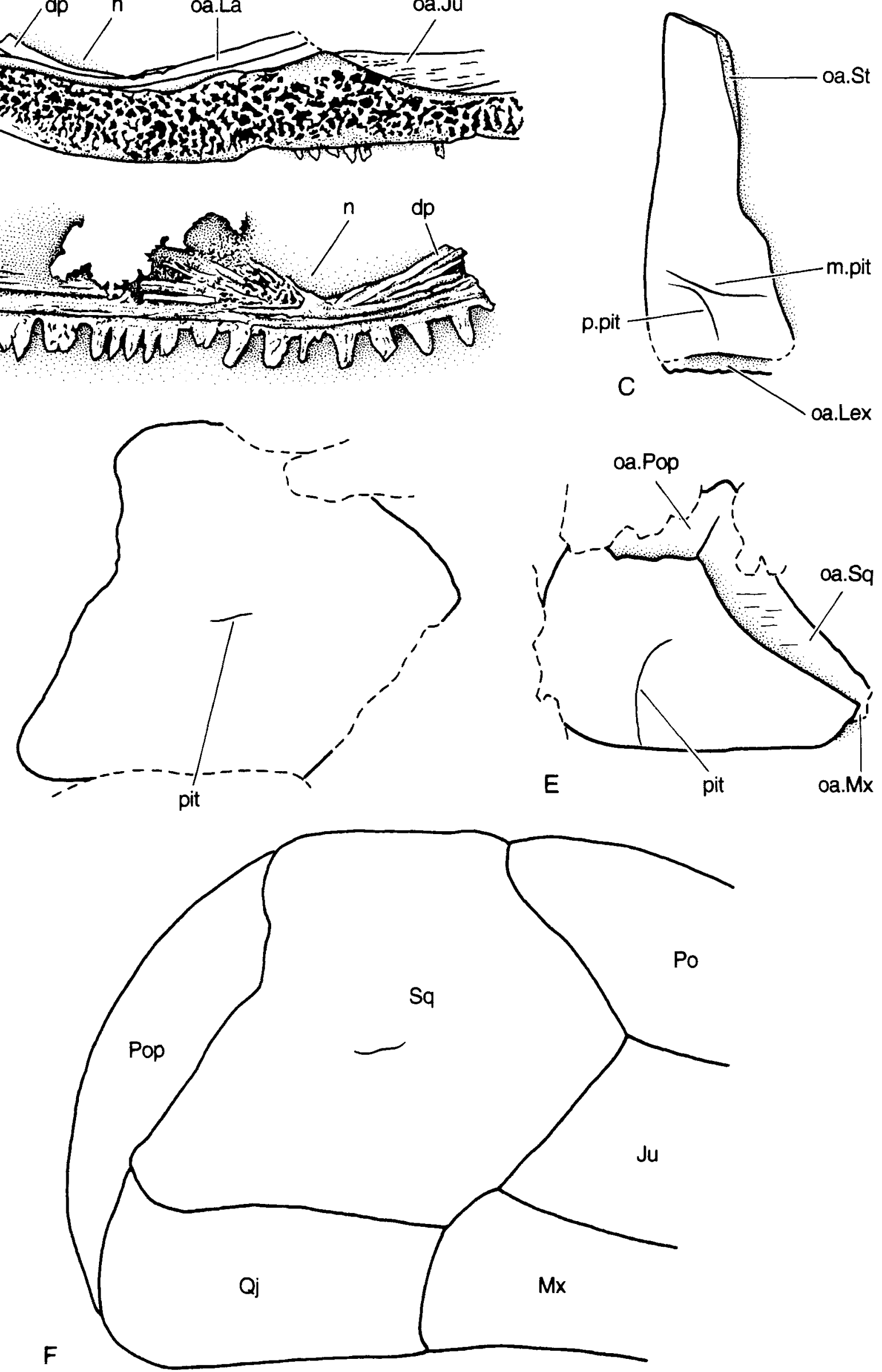
cluding two preserving the external surface and one the internal. One of the specimens preserving the external surface is small, with less strongly developed ornamentation, and likely represents a pre-adult stage of development (Fig. 5D). The postparietals are narrow and elongate anteriorly, broadening posteriorly, with a long edge contacting the supratemporal. The anterior margin is short and somewhat angled. The supratemporal overlap (oa. St) is widest anteriorly, narrowing sharply posteriorly (Fig. 6C). Internally (Fig. 5G, arrow), a shorter surface overlapping onto the tabular bone is preserved. This overlapping surface is of constant width and extends along the entire wider posterior half of the postparietal.

Middle and posterior pitlines (m.pit., p.pit, Fig. 6C) are located near the posterior margin of the postparietal, indicating the position of the growth centre of the bone. This is also visible on the internal surface (Fig. 5G). The posterior margin of the postparietal is horizontal, and a narrow overlap for the median and lateral extrascapular bones is present behind the posterior margin (oa.Lex , Figs 5E, 6C).

Lateral Extrascapular: One lateral extrascapular (Fig. 5C) is referred to Eusthenodon gavini. The anterior margin is oblique, which may be due to postmortem distortion of the bone, as the posterior margin of the postparietal described above (Fig. 5E) and overlapped by the extrascapular is horizontal. Other margins of the extrascapular bone are curved. A long, curved pitline is present in the middle of the bone, but lateral lines are not observed. No overlap surfaces are visible in external view, suggesting that this bone overlapped the median extrascapular, postparietal and tabular. The overlap of the lateral onto the median extrascapular suggests that this bone is not assignable to a porolepiform taxon, which would show the reverse relationship (Jarvik 1972).

Quadratojugal: A right quadratojugal of $E u$ sthenodon gavini is preserved in external view
(AMF107789, Fig. 5F), showing a wide, well-developed overlap for the squamosal occupying nearly the entire anterior margin of the bone (oa.Sq, Fig. 6E). A curved margin separates the overlap from the external ornamented bone surface, which matches other skull bones referred to E. gavini. The squamosal overlap is separated by a sharp angle from the incompletely preserved overlap for the maxilla (oa.Mx). Nevertheless, it appears the overlap area for the maxilla on the quadratojugal would have been small.

The overlap for the preopercular (oa. Pop), though also incomplete, appears to occupy most of the dorsal margin of the quadratojugal. The length of this margin suggests the preopercular would be broad at this point, and the margin separating overlap and ornamented bone here is almost horizontal. The preopercular overlap meets that for the squamosal at a high anterodorsal point. A long, curved pitline (pit) is present in the posteroventral portion of the bone, extending nearly to the ventral margin.

The strongly curved quadratojugal margin contacting the squamosal allows for a taxonomic separation of skull bones from the Hunter Siltstone. The only squamosal so far recognised from this unit (AMF107766, Fig. 7C) shows a reconstructed ventral margin (that overlapping the quadratojugal) that appears to be more horizontal or transverse than convex (Fig. 6D, F). Thus, this margin does not match that of the concave squamosal overlap on the quadratojugal of Eusthenodon gavini, and the ornamentation of these bones also differs (compare Figs 5, 7). The squamosal is referred below to the new genus Yambira.

Scales: Scales from the Hunter Siltstone are referred to Eusthenodon gavini by a process of elimination. Skull bones of E. gavini cannot be associated with porolepiform scales of Holoptychius sp. or Holoptychiidae n. gen. and n. sp., as discussed above. Other scales possessing a more tuberculate ornament are assigned below to the 'osteolepid' Yambira n. gen., based on similarity to ornament on associated skull bones and over-

Fig. 6. A-C, E, Eusthenodon gavini n. sp. A, B, AMF56290, 56289, part and counterpart of partial left maxilla, internal and external views. C, AMF107772, postparietal in external view. E, AMF107789, right quadratojugal in external view. D, F, Yambira thomsoni n. gen. and n. sp. D, AMF107766, squamosal in external view. F, right cheek region based on morphology of squamosal; all other bones reconstructed.

m.pit, middle pitline; $\mathbf{d p}$, dorsal process on maxilla forming choanal notch; Ju, jugal bone; Mx, maxilla; $\mathbf{n}$, notch along maxilla; oa.Ju, area overlapped by jugal; oa.La, area overlapped by lacrimal; oa.Lex, area overlapped by lateral extrascapular; oa. Mx, area overlapped by maxilla; oa.Pop, area overlapped by preoperculum; oa.Sq, area overlapped by squamosal; oa.St, area overlapped by supratemporal; pit, pitline; p. pit, posterior pitline; Po, postorbital; Pop, preopercular; Qj, quadratojugal; Sq, squamosal 
all morphological similarity to scales of other 'osteolepid' taxa (e.g.. Litoptychius. Glyptopomus). The fourth distinct group of scales (Fig. 7E, G, K) is associated with the skull bones of Eusthenodon gavini.

These are thin, cycloid scales. lacking a cosmine cover. Externally, the majority of the scale comprises the overlap areas for adjoining scales. which are marked by concentric growth lines crossed by very fine radiating ridges. The nonoverlapped (ornamented) portion is small and triangular (perhaps one-third of the scale area). The ornamentation within this area is comprises narrow grooves (Fig. 5H. J. L), which are sometimes strongly anastomosing (scale on right side of Fig. $5 \mathrm{H}$ ). In fact, the ornamentation on these scales appears to have been worn to some degree, but this wear is absent on other bones and scales from the Hunter Siltstone.

Certain scales preserve the internal surface with a well-developed central boss (Fig. 5I. K). This boss is seen in the Tristichopteridae (Jarvik 1980) and the Rhizodontida (Andrews 1985. Johanson \& Ahlberg 1998). but also in the rhizodopsids Marsdenichthys Long, 1985a and Rhizodopsis Young. 1866. and in the canowindrid Canowindra grossi Thomson, 1973. However. the ornamented portion on scales of most of these taxa is wider and contains many more distinct ridges (and no grooves) than in Eusthenodon gavini. Scales of Canowindra are covered in small tubercles.

Discussion: Tetrapodomorph skull bones assigned to Eusthenodon gavini can be separated from those referred below to Yambira $n$. gen. based on differences in ornamentation and the incompatibility of certain bones (quadratojugal of E. gavini and squamosal of Yambira n. gen.).

Eusthenodon gavini is assigned to the Tristichopteridae and to Eusthenodon based on similarities to E. wängsjöi (Jarvik 1952. 1985: fig. 37). These include the coarseness of ornamentation on the skull bones and a more horizontal dorsal margin of the quadratojugal contacting the preopercular. The length of this margin suggests the preopercular in these taxa would be broad (Jarvik 1952: pl. 10, Schultze \& Chorn 1998). The dermal ornament in other tristichopterids like Mandageria (Johanson \& Ahlberg 1997), Cabonnichthys (Ahlberg \& Johanson 1997) and Eusthenopteron is not as recognisably coarse or strongly developed, and the preopercular-quadratojugal margin is more oblique.

The dermal ornament of the rhizodopsid Marsdenichthys (originally assigned to the Tristichopteridae. but now referred to the Rhizodopsidae, Long. pers. comm. 1997) is similar to Eusthenodon gavini and $E$. wängsjöi. But again, the contact between quadratojugal and preopercular does not appear to be horizontal in Marsdenichthys (Long 1985a: fig. 1B; bone dorsal to 'QJ').

Eusthenodon gavini is described as a new species based on differences in scale morphology relative to $E$. wängsjöi. In the latter, scales were described as having a comparatively large overlapped portion (as in E. gavini), but with ornament composed of ridges forming networks (Jarvik 1952). An accompanying figure (Jarvik 1952: fig. 30) shows the ornamented area to be horizontal across the posterior edge of the scale rather than triangular as in E. gavini. Also, the ridges appear more strongly developed than in E. gavini, and grooves do not appear present.

Tetrapodomorpha Ahlberg, 1991 Family "Osteolepidae" Cope, 1889

Yambira n. gen.

Diagnosis: As for type and only known species.

Etymology: For Yambira Mountain, SE of Redcliff Mountain in the Warrumba Range. The Hunter Siltstone also outcrops here, and preliminary investigation suggests a fauna comparable to the Redcliff Mountain sites is present.

\section{Yambira thomsoni n. sp.}

Figs 6D, F, 7A-H, K-N

Holo1ype: AMF107766, squamosal (Fig. 7C).

Paratypes: AMF107779, left intertemporal; AMF107809, AMF107821. AMF107454-5, AMF107817, AMF107821. AMF107960. ANU47070 nasal or rostral bones; AMF107787.

Fig. 7. A-H. K-N. Yambira thomsoni n. gen. and n. sp. A. AMF107779. left intertemporal bone in external view. Arrow marks overlap surface of postorbital bone. $\times 1.1$. B. AMF107787. anocleithrum or preopercular in external view, $\times 1.3$. C, AMF107766. left squamosal in external view: $\times 1.2$. D. AMF107779, closeup of tuberculate ornament (compare to Fig. 3E). E, AMF107791. scale in external riew: $\times 1.3$. F. AMF107455. nasal or rostral bone in external view, $\times 1.4$. G. AMF107788, scale in external view, $\times 1.9$. H. AMF107790, scale in external view: $\times 1.2$. I. AMF107970, holoptychiid (porolepiform) postparietal shicld in internal view. $\times 1.2$. J. AMF78721. tetrapodomorph pectoral fin radial. $\times 1.1$. K. AMF107786, scale in external view. $\times 0.91$. L. AMF107809. ×1.4. M. AMF107455. ×1.3. N. AMF107821. ×1.3. All nasal or rostral bones in external view 

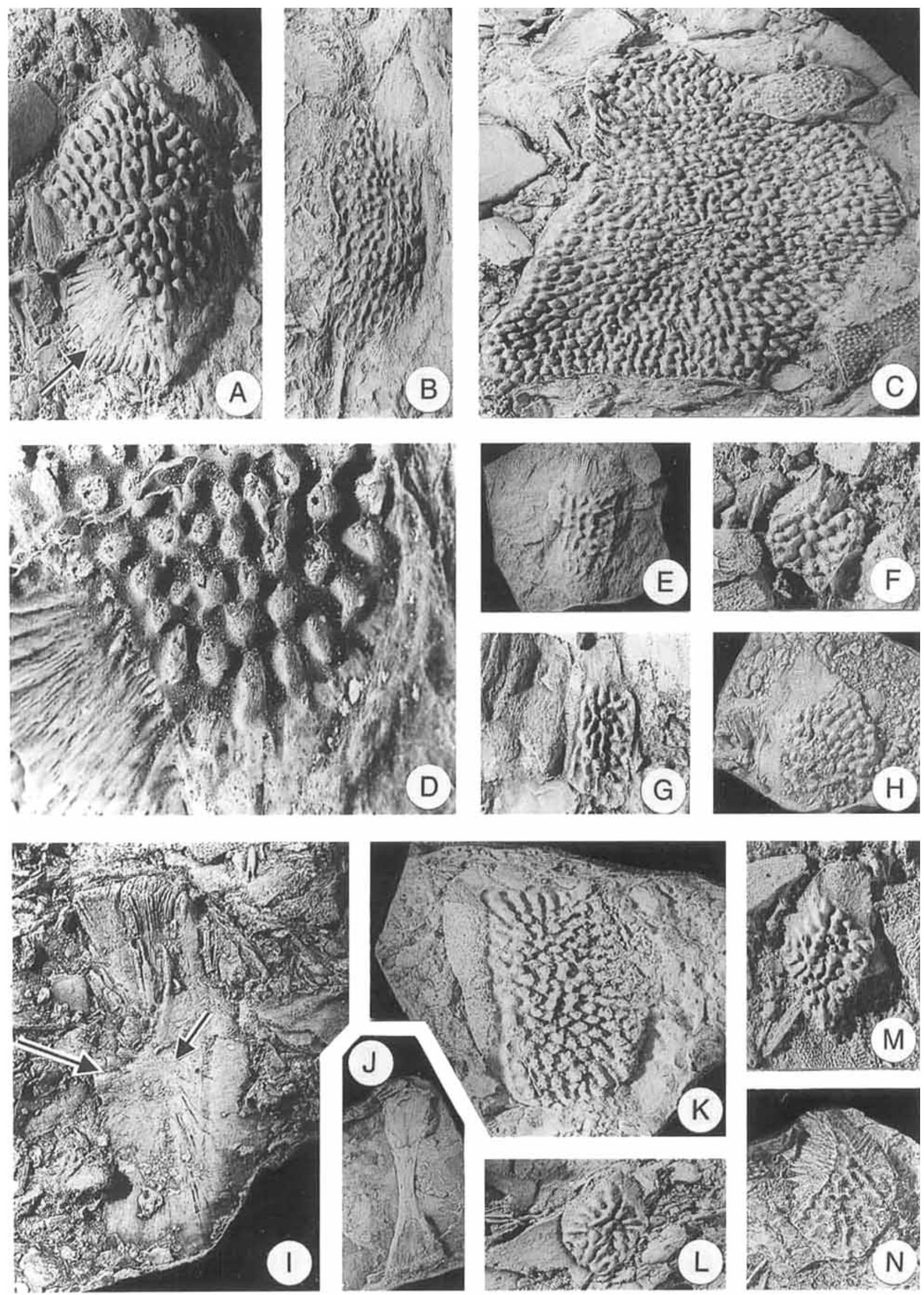
anocleithrum or preopercular: AMF107786. AMF107790. AMF107791. AMF107788. AMF107802. AMF107972. scales: AMF107775. AMF107801. AMF107803, AMF107810. AMF107814. skull bone fragments.

Diagnosis: Differs from other 'osteolepids' in the absence of cosmine and the presence of coarse tuberculate ornament on skull bones and scales. Among coarsely tuberculated 'osteolepids'. differs from Glyptopomus in having a diamond-shaped, rather than more rectangular intertemporal bone and a larger postorbital, and differs from Litoptychius in having a preopercular contacting the squamosal along most of its length rather than being separated by the quadratojugal.

Etymology: For Keith Thomson. Oxford University, for his ongoing contributions to the study of sarcopterygian fishes.

Occurrence: Upper part of the Hunter Siltstone (Upper Famennian), Redcliff Mountain, $15 \mathrm{~km}$ NE of Grenfell. New South Wales. Australia.

Remarks: Comparison of Yambira thomsoni to the taxa like Glyptopomus (Jarvik 1950b) is based, in part, on the morphology of the squamosal (Fig. 7C). which appears to have a horizontal or transverse ventral margin contacting the quadratojugal. This seems more typical of various taxa assigned to the "Osteolepidae" (Lebedev 1995, Long et al. 1997) and the Megalichthyidae (Fox et al. 1995). Of these, comparable ornamentation of the skull bones and scales occurs within the 'Osteolepidae' (Litoptychius [Denison 1951, Schultze \& Chorn 1998] and Glyptopomus).

The monophyly of the 'Osteolepidae' is uncertain (e.g., Ahlberg \& Johanson 1998). Young et al. (1992) suggested that the presence of an extratemporal bone was a synapomorphy of the 'Osteolepidae'; however, this bone is also present in phylogenetically basal Rhizodontida (Barameda Long, 1989; Gooloogongia), the Canowindridae (Young et al. 1992), as well as onychodontiforms (Schultze 1973, Cloutier \& Ahlberg 1996). porolepiforms (Jarvik 1972), and the dipnomorph Youngolepis (Chang 1982, 1991). Other authors have also had difficulty finding apomorphic character states for the 'Osteolepidae' (Long 1985a. b. Lebedev 1995). Although these problems are as yet unresolved, Yambira thomsoni is assigned to the 'Osteolepidae' because closest comparisons are to taxa assigned to this family.

Description:

Squamosal: The holotype of Yambira thomso$n i$ is a large bone (Fig. 7C), regarded as a squa- mosal based on its shape and the presence of a small pitline in the middle of the bone (pit, Fig. 6D). This bone is preserved in external view, and while a large proportion of the squamosal margins are covered by sediment or isolated bones, the posterior margin and the posteroventral corner are complete.

The posterior margin of the squamosal can be divided into a straighter dorsal portion and a somewhat oblique ventral portion. The entire posterior margin is occupied by the preopercular. as in other tetrapodomorphs (e.g., Glyptopomus [Jarvik 1950b], Eusthenopteron [Jarvik 1980]. Gogonasus [Long et al. 1997]). The course of the jugal canal through the central pitline and across the squamosal is not preserved.

The remaining margins of the squamosal are incomplete, but most of the bone is nevertheless believed to be present (Fig. 6D, F). The anterior margin is angled anteriorly, separating contacts for the postorbital ( $\mathrm{Po}$ ) and jugal bones (Ju). A more ventral angle separating the contacts for the jugal and maxilla is either not well preserved or is poorly developed.

The ventral margin of the squamosal is also largely incomplete, although the posteroventral corner of the bone is preserved. The shape of this corner, and the short length of ventral margin that continues forward from this corner, strongly suggests that the ventral margin of the squamosal was more transverse than oblique or curved (Fig. 6D, F). That is, the ventral margin does not angle sharply ventrally from the posteroventral corner, as would be expected for the squamosal associated with the quadratojugal of Eusthenodon gavini described above (Fig. 6E).

Intertemporal: The specimen AMF107779 (Fig. 7A) represents an intertemporal, a large bone preserving a coarsely tuberculate ornamentation comparable to other bones referred to Yambira. The intertemporal is diamond shaped, with a strongly developed posterolateral overlap (arrow, Fig. 7A) for the dorsal margin of the postorbital. Again, no sensory canals are observed on this bone.

Preoperculum/anocleithrum: Specimen AMF 107787 (Fig. 7B) appears to be an elongate bone with ornament again matching that of the squamosal. There is a triangular overlap surface, which is believed to have been oriented dorsally. A second overlap at the ventral margin of the bone is not visible; if this absence is real, the morphology would be most similar to a preopercular bone. Alternatively, the bone lacks the pre- 
opercular pitline (e.g., Jarvik 1980: fig. 115), so that if a ventral overlap area were present but hidden, the morphology would be more similar to the anocleithrum.

Nasal/rostral bones: Several small bones are preserved (Fig. $7 \mathrm{~F}, \mathrm{~L}-\mathrm{N}$ ), roughly diamondshaped with overlap surfaces running along two adjoining sides and separated by a ridge. Given their size, they are suggested to be the bones of the nasal or rostral series (although no supraorbital canal is seen, as would be expected on the nasal series). The ornament of these also matches that of the bones described above, rather than that of Eusthenodon gavini.

Scales: By comparison to Litoptychius (Denison 1951, Schultze \& Chorn 1998: fig. 17) and Glyptopomus (Jarvik 1950b), four specimens with coarse dermal ornament are considered to be scales, rather than skull bones. On these, a narrow overlap area runs along one side of the scale, continuous with a wider overlap along the dorsal margin of the scale (Fig. 7E, G, H, K). A small peg-like or triangular structure is situated on this dorsal margin on most of the referred scales. On 'osteolepid' scales, a groove separates the overlapped from the non-overlapped areas (Jarvik 1948, 1950a, b, Schultze \& Chorn 1998: fig. 17). In Yambira, this groove is best preserved on AMF107786 (Fig. 7K).

Only a small number of rhipidistian taxa have scales covered in a strong dermal ornament, including Glyptopomus (Jarvik 1950a: pl.4.3), Litoptychius (Denison 1951: fig. 47A, Schultze \& Chorn 1998: fig. 17), Platycephalichthys Vorobyeva, 1959 (Vorobyeva 1977: pl. 12.7), Lamprotolepis Vorobyeva, 1977 (Vorobyeva 1977: pl. 10.12, 10.13), certain scales of Gyroptychius groenlandicus Jarvik, 1950b (Jarvik 1950b: pl.22.3, 22.4), and Panderichthys Gross, 1941 (Gross 1933a: pl. 6.5, 1966: fig. 6D). Of these, scales of Yambira are most similar to Litoptychius and Glyptopomus in the appearance of the ornament.

Discussion: The morphology of the contact between the squamosal and quadratojugal of Yambira appears most typical of taxa assigned to the 'Osteolepidae' such as Gogonasus (Long et al. 1997), Medoevia (Lebedev 1995: fig. 8E, G) and Glyptopomus (Jarvik 1950a: pl. 7), whereas absence of cosmine on the skull roofing bones is characteristic of the latter. Long et al. (1997: 19) noted that the squamosal-quadratojugal contact in Gogonasus and Gyroptychius M'Coy, 1848 was unusual with regards to other 'osteolepids' like Osteolepis Agassiz, 1835 and Thursius Tra- quair, 1888 in that the squamosal overlapped more of the quadratojugal relative to the maxilla. This also occurs in Glyptopomus (Jarvik 1950a: pl. 8.1), and is included in the reconstruction of the cheek region of Yambira (Fig. 6F).

Scale morphology is closest to Litoptychius and Glyptopomus within the 'Osteolepidae'. Schultze \& Chorn (1998: 68) associated scales with skull bones of Litoptychius based on similarity in ornamentation; this was also the criterion used for Yambira. Some scales of Litoptychius were said to be partially covered in cosmine (ibidem), while cosmine is absent from all sarcopterygian scales and skull bones in the Hunter Siltstone. Jarvik (1950b) noted that scales of cosmine-covered 'osteolepids' like Thursius and Osteolepis did, rarely, lack a full cosmine cover, although he attached no taxonomic significance to this.

Litoptychius differs from Yambira in the relative size and morphology of bones in the cheek region (squamosal and quadratojugal) and in the fusion of bones in the snout (Schultze \& Chorn 1998). The contact between the squamosal, quadratojugal and preopercular in Litoptychius is unusual (probably apomorphic) in that the quadratojugal occupies much of the posterior margin of the squamosal, restricting the preopercular to a small dorsal contact. The cheek of Yambira is more similar to Glyptopomus (Jarvik 1950a: pl. 7.1), but the scale ornament is not as tuberculate in the latter (Jarvik 1950a: pls 4.3, 6.4). Additionally, the intertemporal of Yambira is strongly diamond-shaped (and more similar to that of Eusthenopteron [Jarvik 1980]), while that of Glyptopomus (Jarvik 1950a: pls 2-4) is triangular or more rectangular.

\section{Tetrapodomorph postcranial material}

A number of specimens from the Hunter Siltstone (AMF107797A, B, AMF112209, AMF78721 and AMF107453) represent tetrapodomorph postcranial elements. These cannot be confidently associated with Eusthenodon gavini or Yambira thomsoni and so are described separately below, and compared to well-illustrated specimens of Eusthenopteron (Andrews \& Westoll 1970a).

The first specimen, AMF107797A (Fig. 3F), represents a radial in either the dorsal or anal fin of a larger tetrapodomorph. The proximal end is narrow and circular, and does not appear flattened. The shaft of the radial is twisted slightly, 
and a distinct ridge is formed along one edge of the radial. At the narrowest part of the radial, this ridge crosses to the other side of the specimen. There may be a shallow groove associated with this ridge, particularly at this point. Three radials support the posterior dorsal and anal fins in Eusthenopteron (Andrews \& Westoll 1970a: pl. 5C), and AMF107797A is similar to the most posterior of these in flaring distally. However, all three Eusthenopteron radials differ from AMF107797A in lacking a twist in the shaft. as well as the associated ridge and groove.

Specimen AMF107797A may show closest similarity to fin radials provisionally assigned to the tristichopterid Hyneria Thomson, 1968, from the Famennian Catskill Formation of Pennsylvania (specimens held at the National Academy of Sciences, Philadelphia) in possessing a rounded proximal end, a slight twist to the radial shaft. and a flared distal end. Hyneria is otherwise a poorly known tristichopterid (Ahlberg \& Johanson 1997), and assignment of AMF107797A will wait until new material from the Catskill Formation is described by E. B. Daeschler.

Specimens AMF112209 and AMF78721 (Figs $3 \mathrm{G}, 7 \mathrm{~J}$ ) are much smaller, and may be radials from the pectoral fin (Andrews \& Westoll 1970a: pl.3). These elements are stout, and the proximal and distal ends are of equal size, while the shaft of the radial narrows between them. Each end is wide, but the proximal end is rounder than the distal and preserves an attachment surface of unfinished bone. The distal end is flattened, and its edge is divided into two by a low. but clear ridge (AMF112209) or consists of a depressed triangular area (AMF78721). Thus, the proximal end attaches to the bone anterior to it in the pectoral fin, and the distal end articulates with lepidotrichia. An alternative interpretation is that these may be lungfish median fin radials (P. Ahlberg, pers. comm. 2000), although these are often more elongate and less stout. A toothplated lungfish has been described from the Grenfell fauna (Johanson \& Ritchie 2000): if AMF11220 and AMF78721 do represent lungfish median fin radials, they would associate well with anal fin plates recognised by Johanson \& Ritchie (2000). These have a triangular basal plate supported by a long cylindrical shaft, similar to lungfish such as Soederberghia (Ahlberg et al. in press) and Scaumenacia (Cloutier 1996). By comparison, medial fins of lungfish taxa like Dipterus (Ahlberg \& Trewin 1995) possess a simple basal plate (lacking a shaft) and short. blocky radials in the fin.
The fourth specimen (AMF107453, Fig. 3H, I) may represent a tetrapodomorph anal fin support. What is interpreted as the proximal end of AMF107453 is wide and flattened (arrow, Fig. $3 \mathrm{H}$ ), and in Eusthenopteron, would attach to two haemal spines (Andrews \& Westoll 1970a). The proximal process on AMF107453 is short and wide relative to that figured for Eusthenopteron and Megalichthys (Andrews \& Westoll 1970b: fig. 8c). The process on AMF107453 widens distally into a base for the support of the fin radials (the unpaired fin radial AMF107797 described above is too large to be associated with AMF107453, and would belong to a second individual). The base of AMF107453 flares and curves anteriorly, a feature not as well developed in other tetrapodomorphs (Andrews \& Westoll 1970a, b).

Three rounded attachment surfaces are present along the distal edge of the fin base, which is straight rather than stepped. Andrews \& Westoll (1970a: 290) noted this was more characteristic of the anal fin rather than the second dorsal fin support. The attachment surface for the posterior radial is the largest (Fig. 3I, arrow), while that for the most anterior is very small. This suggests a size difference in the fin radials not observed for Eusthenopteron (Andrews \& Westoll 1970a: fig. 28) or other tetrapodomorphs (Andrews \& Westoll 1970b: figs 1, 5, 14). As well, these attachment surfaces occupy only slightly more than half of the distal edge of the fin support, while in other tetrapodomorphs, the entire distal surface is occupied (Andrews \& Westoll 1970a, b).

Among dipnomorph taxa, the posterior radials of the second dorsal fin are supported by a complex branching structure, while the more anterior radials attach directly to the basal plate (Glyptolepis, Dipterus, Ahlberg 1991: figs 1, 2). The posterior branching element might correspond to a relatively larger attachment surface on the basal plate, comparable to AMF107453. However, the base of this complex structure (and its corresponding attachment surface) does not appear much larger than the more anterior radials (Andrews \& Westoll 1970b, Ahlberg 1989, 1991, Ahlberg \& Trewin 1995: figs 5, 9). Additionally, these second dorsal fin supports appear to have attachment spaces for approximately five radials; AMF107453 has only three, which is comparable to Eusthenopteron.

At least two of the postcranial elements described above (AMF107797, AMF107453) can be confidently identified as tetrapodomorph, 
while the other two (AMF112209, AMF78721) may be dipnomorph, and more specifically, lungfish. With regards to above AMF107797 and AMF107453, it is not certain whether these should be assigned to Eusthenodon gavini, Yambira thomsoni or a new species altogether.

\section{Palaeobiogeography}

The presence of the antiarch family Sinolepidae on the North and South China terranes and in the Hunter Siltstone near Grenfell (East Gondwana) suggests proximity of these areas during the Late Devonian (Burrett et al. 1990, Ritchie et al. 1992, Young \& Janvier 1999). The sister group relationship between the sinolepids Grenfellaspis (Hunter Siltstone) and Sinolepis (Wutung Group, Zhongning and Sanmentan formations; Yang et al. 1981, Young et al. 1992, Wang 1993) restricts this terrane proximity to the Late Devonian (Famennian), and is used to establish a time frame for the rifting of these terranes from the Gondwanan margin (Metcalfe 1996). Conversely, Young \& Janvier (1999: fig. 1) suggested that Asian terranes are isolated from Gondwana through much of the Silurian-Devonian, and used the sinolepid distribution to establish contact between these areas only in the latest Famennian.

Several taxa have now been described from the Hunter Siltstone, including the antiarchs $B o$ thriolepis grenfellensis and Remigolepis redcliffensis (Johanson 1997a) and a new tooth-plated lungfish (Johanson \& Ritchie 2000). Acanthodian material is currently being studied by J. A. Long, and the unornamented Groenlandaspis by A. Ritchie. Other faunal similarities between the Hunter Siltstone and the Asian terranes include the geographically widespread Bothriolepis and Remigolepis; as well, rhipidistian scales (both dipnomorph and tetrapodomorph taxa) have been described from the Wutung Group in association with Sinolepis macrocephala and $S$. wutungenesis (Liu \& Pan 1958, Pan 1956, 1957a, b, 1964, Yang et al. 1981: tab. 4). Sarcopterygian scales have also been found in the Zhongning Formation associated with several species of $R \boldsymbol{e}^{-}$ migolepis (Pan et al. 1987, Zhu Min, pers. comm. 1999), but are as yet undescribed.

Johanson (1997a) could not identify derived characters shared between Remigolepis redcliffensis and the Chinese Remigolepis species, relative to species described from East Greenland, other parts of Europe and Australia (Johanson 1997b). Potential for further comparison includes the morphology of the overlap surface on the anterior dorsolateral plate (ADL) of the trunkshield for the submarginal of the headshield. This overlap has an unusual morphology in $R$. redcliffensis, but was not clearly visible in figures of the Chinese Remigolepis species (Pan et al. 1987). The overlap surface in $R$. redcliffensis may differ from that on the ADL of Remigolepis walkeri Johanson, 1997b from Canowindra, NSW (contra Johanson 1997b: 840), related to differences in the processus obstans on this plate. The processus obstans was said to be smaller on $R$. redcliffensis relative to other species of Remigolepis (Johanson 1997b), but again, the Chinese Remigolepis could not be readily evaluated.

The attachment surface on the lateral plate of the headshield for the submarginal plate in $B o$ thriolepis grenfellensis appears to be a taxonomically useful character (e.g., Young 1988). Bothriolepis is present in the Famennian of China, but not yet described (e.g., Pan et al. 1987: tab. 4). Future work will explore these antiarch characters in more detail.

Rhipidistian scales from the Wutung Group (Pan 1957a, 1964, Liu \& Pan 1958, Wang 1984, Yang et al. 1981) were originally referred to the Dipteridae (based on the suggested presence of Westoll lines [Liu \& Pan 1958]) and, questionably, to the porolepiform Laccognathus Gross, 1941. The names Paraholoptychius lungtanensis (= Dipterus lungtanensis) and ?Holoptychius nankinensis were applied to the dipterid scales (Pan 1964: 144, these names also appear in later summaries of Chinese faunas [Wang 1984, Yang et al. 1981]). However, it does not appear that these taxa were formally described (Zhu Min, pers. comm. 1999), and so are nomina nuda. Additionally, Pan (1964) noted similarity between a scale of ?Holoptychius nankinensis and scales of Eusthenopteron, assigning this to E. nankinensis (Pan 1957a, Liu \& Pan 1958: pl. 9.2, Zhu Min, pers. comm. 1999). It is important to note that Holoptychius scales do not appear to occur in the Wutung Group (among those figured by Liu \& Pan [1958]]), and that these, regardless of the names used, were originally assigned to the Dipteridae (Liu \& Pan 1958, contra Pan 1956).

This dipterid assignment is followed herein, although it is not clear that any scales figured by Liu \& Pan (1958: pls 9, 10) possess Westoll lines, which are associated with a covering of cosmine. Similarities between these and scales referred to the new tooth-plated dipnoan taxon from the Grenfell fauna are not striking; the ornamented 
field of the latter consists of a very sparse covering of tubercles (Johanson \& Ritchie 2000). Dipnoan scales from the Wutung Group have a broad ornamented field packed with small, closely spaced tubercles (Liu \& Pan 1958: pl. 10.1-10.3). Dipnoan dental material (usually readily preserved) has not been described from Sinolepis-bearing units.

The scale of Eusthenopteron nankinensis (Liu \& Pan 1958: pl. 9.2) is preserved in external view (the presence of a boss on the internal surface cannot be determined). and possesses an ornamented field filled with many thin ridges. This morphology is also seen in Eusthenopteron and Eusthenodon wängsjöi (Jarvik 1952) and the Canowindra tristichopterids (Ahlberg \& Johanson 1997, Johanson \& Ahlberg 1997), but also occurs in rhizodonts and certain lungfish (lungfish scales lack an internal boss). Scales of Eusthenodon gavini from the Hunter Siltstone are marked by thin grooves (often anastomosing) and differ from the above tristichopterids and Eusthenopteron nankinensis.

Porolepiform scales assigned to Laccognathus (Liu \& Pan 1958: pl. 10.4. 10.5) possess a wide ornamented field with numerous large tubercles. This differs from the Grenfell porolepiforms, which comprise two holoptychiid taxa, including Holoptychius. Laccognathus has also been described from Eastern Europe (Gross 1941, Ørvig 1957, Vorobyeva 1980), but is not known from eastern Australia (Young 1993). Holoptychius has thus far not been described from Asian faunas in association with Sinolepis, nor have the distinct scales of Holoptychiidae $\mathrm{n}$. gen. and n. sp.. described above. Scales of the 'osteolepid' Yambira thomsoni (Fig. 7E, G, H, K) also have no counterpart in the Wutung Group.

As noted above, distribution and phylogenetic relationships of the sinolepid antiarchs suggest that certain southeast Asian terranes share a biogeographic relationship with Eastern Australia in the latest Devonian (Burrett et al. 1990. Ritchie et al. 1992, Metcalfe 1996. Young \& Janvier 1999). However, as descriptive work on the Grenfell fauna progresses, it appears that faunal similarities with the North and South China terranes beyond the sinolepid antiarchs are somewhat limited.

Indeed. sinolepids are recognised in the Lower Devonian of China (Young et al. 1992). but in eastern Gondwana have (other than the Hunter Siltstone), only been identified from the latest Devonian Bumberry Formation. not far from Grenfell (Young 1999: fig. 5). Sinolepids are ab- sent from older, late Frasnian and Famennian NSW faunas (including the Mandagery Sandstone. Cloghnan Shale [Jemalong Range near Forbes] and Worange Point [near Eden]), which may be contrary to expectations if the Asian terranes originated along the margins of northern Gondwana (Metcalfe 1996) and show some type of connection with east Gondwana in the latest Devonian. These other NSW faunas instead show similarities to faunas from several Northern Hemisphere localities.

For example, the Canowindra fauna (Mandagery Sandstone, upper Frasnian, Young 1999) includes two tristichopterids (Mandageria fairfaxi Johanson \& Ahlberg, 1997 and Cabonnichthys burnsi), closely related to Eusthenodon (Jarvik 1952. Ahlberg \& Johanson 1997). Eusthenodon occurs in Famennian deposits of East Greenland, the Tula region of Russia (Lebedev 1992), and Pennsylvania (E. B. Daeschler, pers. comm. 1998). A closely related tristichopterid also occurs in Famennian Worange Point Formation in NSW.

Additionally, a new species of the rhynchodipterid lungfish Soederberghia Lehman, 1959 was recently described from the Mandagery Sandstone (Ahlberg et al. in press); Soederberghia groenlandica occurs in the nearby Jemalong locality (Famennian [Campbell \& Bell 1982]), East Greenland (Lehman 1959) and Pennsylvania (Ahlberg et al. in press).

The distinctive scales of the porolepiform $\mathrm{Ho}$ loptychius have been recognised in East Greenland and Pennsylvania ( $\mathrm{K}$. Thomson, pers. comm. 2000), and in NSW in the Worange Point Formation and the Jemalong locality (Young 1993). They have not been identified in the Mandagery Sandstone near Canowindra, although this may correspond to the late Frasnian age of this unit (Young 1999, Ahlberg et al. in press).

Some of these taxa have also been identified in the Hunter Siltstone, for example, Holoptychius sp. and Eusthenodon gavini. Yambira thomsoni was referred to family 'Osteolepidae', possessing scales compared above to taxa like Litoptychius or Glyptopomus. This type of ornamented scales has not been recognised in the Mandagery Sandstone or Cloghnan Shale. However, a cosmine-covered 'osteolepid' is present in the Worange Point Formation near Eden, and interestingly, shows strong ornamentation underneath a thin cosmine cover on the scales. As noted above, presence or absence of cosmine cover on the scales may have less taxonomic significance than the overall morphology of the 
scale. Further work may establish additional similarity between 'osteolepids' from the Hunter Siltstone and Worange Point Formation. Also to be considered in more detail is the large tristichopterid from the Worange Point Formation, and its relationship to Eusthenodon. A preliminary examination of the Worange Point scales (pers. observation) indicates little similarity to $E$. gavini, possessing a broadly triangular ornamented area crossed by sharp ridges.

The above taxonomic similarities may reflect the Fammenian age of the Grenfell fauna, but there are also differences. Scales of the second holoptychiid porolepiform from the Hunter Siltstone appear to be closely similar to a form from the Givetian of Estonia (P. E. Ahlberg, pers. comm. 2000), and the cleithrum of Grenfellia cannot be easily compared to any sarcopterygian. Nevertheless, the rhipidistian fauna from the Hunter Siltstone shows more similarity to other Famennian NSW and northern hemisphere faunas than to those from Asian terranes. More work is needed on Asian faunas, but perhaps most surprising thus far is the absence of the readily recognisable and widely distributed $\mathrm{Ho}$ loptychius.

The position of the Asian terranes, closer to what is now the northern corner of Western Australia (Metcalfe 1996: fig. 13), may account for the reduced similarity to eastern Australian faunas. Alternatively, Zhao et al. (1996) suggested that these terranes began to rift away in the Middle Devonian. Young \& Janvier (1999) supported a pre-Silurian separation for several Asian terranes, including the South China block, with a Gondwanan connection established in the latest Devonian, to account for the sinolepid distribution. Young \& Janvier (1999: fig. 1) isolated an east Asian composite terrane in the PalaeoPacific until the latest Devonian. Affinity of other Frasnian and Famennian NSW faunas to Euramerican faunas, and absence of sinolepid antiarchs in eastern Gondwana prior to the latest Devonian, provide some support for the suggestions of Young \& Janvier (1999).

Palaeomagnetic evidence suggests eastern Gondwana and Euramerica were widely separated in the Late Devonian, and a dispersal route across the North and South China terranes was proposed to account for the faunal similarities between eastern Gondwana and Euramerica (Li et al. 1993). This suggestion has been criticised (Rich \& Young 1996, Young \& Janvier 1999), based on the absence of several otherwise widely distributed taxa from these terranes, to which can be added the majority of rhipidistian taxa described from the Hunter Siltstone. Instead, biogeographic affinities between Gondwana and Euramerica can be based on proximity of these landmasses in, and possibly prior to, the Late Devonian.

\section{Acknowledgments}

We thank Bill and Sue White and family (Grenfell), for allowing access to their land for nearly 30 years. Many volunteers have assisted with the ongoing excavations, and their efforts have been invaluable. Mr. James Fairfax (Sydney) is thanked for his generous, ongoing contributions to our research. Monica Yeung (Gondwana Dreaming Pty., Canberra) is thanked for organising a field excursion to Grenfell in 1998. John Laurie (AGSO, Canberra) made available Grenfell material held in AGSO collections. Ken Campbell (Australian National University, Canberra) also arranged for loan of material held in ANU collections. Ted Daeschler (Academy of Natural Sciences, Philadelphia) also allowed the authors to examine specimens under his care, and provided prepublication images of Hyneria fin radials. Zhu Min (IVPP, Beijing) provided valuable assistance in resolving the validity of taxa described from the Wutung Group. Angela Brown (Newcastle upon Tyne), and Sue Turner (Queensland Museum) generously provided access to unpublished work on Holoptychius. Per Ahlberg, Jenny Clack, Mike Coates. Ted Daeschler, Philippe Janvier, John Long, Hans-Peter Schultze and Keith Thomson are thanked for discussion and their comments. Hans-Peter Schultze has translated the abstract into German. ZJ is supported by an ARC Postdoctoral Research Fellowship.

\section{References}

Agassiz, L. 1833-1844. Recherches sur les Poissons Fossiles. Neuchâtel et Soleure, Petitpierre.

Ahiberg, P. E. 1989. Paired fin skeletons and relationships of the fossil group Porolepiformes (Osteichthyes: Sarcopterygii). - Zoological Journal of the Linnean Society 96: 119-166.

- 1991. A re-examination of sarcopterygian interrelationships, with special reference to the Porolepiformes. $-\mathrm{Zo}$ ological Journal of the Linnean Society 103: $241-287$.

- 1992. A new holoptychiid porolepiform fish from the Upper Frasnian of Elgin, Scotland. - Palaeontology 35: $813-828$.

Ahlberg, P. E. \& Johanson, Z. 1997. The second tristichopterid (Sarcopterygii, Osteolepiformes) from the Upper Devonian of Canowindra, New South Wales, Australia. Journal of Vertebrate Paleontology 17: 653-673.

- 1998. Osteolepiforms and the ancestry of tetrapods. Nature 395: 792-794.

Ahlberg, P. E., Johanson, Z. \& Daeschler, E. B. In press. The Late Devonian lungfish Soederberghia (Sarcopterygii, Dipnoi) from Australia and North America, and its biogeographical implications. - Journal of Vertebrate Paleontology.

Ahlberg, P. E. \& Trewin, N. H. 1995. The postcranial skeleton of the Middle Devonian lungfish Dipterus valenciennesi. - Transactions of the Royal Society of Edinburgh: Earth Sciences 85: 159-176.

Andrews, S. M. 1985. Rhizodont crossopterygian fish from the Dinantian of Foulden, Berwickshire, Scotland, with a re-evaluation of this group. - Transactions of the Royal Society of Edinburgh: Earth Sciences 76: 67-95. 
Andrews. S. M. \& Westoll. T. S. 1970a. The postcranial skeleton of Eusthenopteron. - Transactions of the Royal Society of Edinburgh: Earth Sciences 68: 391-489.

- 1970b. The postcranial skeleton of rhipidistians excluding Eusthenopteron. - Transactions of the Royal Society of Edinburgh: Earth Sciences 68: $391-489$.

Barwick, R. E. \& Campbell. K. S. W. 1996. A Late Devonian dipnoan. Pillararhynchus. from Gogo. Western Australia. and its relationships. - Palaeontographica A 239: 1-42.

Blieck. A. 1985. Paleoenvironments de Heterostraces. Vértebrés agnathes ordoviciens a Dévoniens. - Bulletin du Musćum National d'Histoire Naturelle. 4e Serie 7: $143-155$.

Blieck. A. \& Janvier. P. 1991. Silurian vertebrates. In Bassett. M. G. Lane. P. D. \& Edwards. D. (eds). The Murchison Symposium: Proceedings of an international conference on the Silurian System. Special Papers in Palaeontology 44: $345-390$.

Brown. A. K. 1978. The Scottish Devonian crossoptervgian fish Holoptychilus. Unpublished Ph.D. thesis. University of Newcastle upon Tyne. $300 \mathrm{pp}$.

Burrett. C.. Long. J. \& Stait. B. 1990. Early-Middle Palaeozoic biogeography of Asian terranes derived from Gondwana. In McKerrow. W. S \& Scotese. C. R. (eds). Palaeozoic Palaeogeography and Biogeography. Geological Society of London Memoir 12: 163-174.

Campbell. K. S. W. \& Barwick. R. E. 1987. Palaeozoic lungfishes - a review. - Journal of Morphology: Supplement 1: $93-131$.

- 1988. Uranolophus: a reappraisal of a primitive dipnoan. In Jell. P. A. (ed.). Devonian and Carboniferous fish studies. Association of Australasian Palaeontologists Memoir 7: $87-142$.

- 1990. Paleozoic dipnoan phylogeny: functional complexes and evolution without parsimony. - Paleobiology 16 $143-169$.

- 1999. Dipnoan fishes from the Late Devonian Gogo For mation of Western Australia. - Records of the Western Australian Museum Supplement 57: 107-138.

Campbell. K. S. W. \& Bell. M. W. 1982. Soederberghia (Dipnoi) from the Late Devonian of New South Wales. - Alcheringa 6: $143-150$.

Chang Meemann 1982. The braincase of Youngolepis. a Lower Devonian crossopterygian from Yunnan. southwestern China. - Papers in the Department of Geology. University of Stockholm. $112 \mathrm{pp}$

- 1991. Head exoskeleton and shoulder girdle of Youngolepis. In Chang. M.-M.. Liu. Y. \& Zhang. G. (eds). Early Vertebrates and Related Problems of Evolutionary Biology: 355-378. Science Press. Beijing.

Chang Meemann \& Yu Xiaobo 1981. A new crossopterygian Youngolepis praecursor gen. et sp. nov. from Lower Devonian of E. Yunnan. China. - Scientia Sinica 24: 89-97.

Cloutier. R. 1996. The primitive actinistian Miguashaia bureaui Schultze (Sarcopterygii). In Schultze. H.-P. \& Cloutier. R. (eds). Devonian Fishes and Plants of Miguasha. Quebec. Canada: 227-247. Verlag Dr. Friedrich Pfeil. München.

Cloutier. R., \& Ahlberg. P. E. 1996. Morphology. characters and the interrelationships of basal sarcopterygians. In Stiassny. M. L. J. Parenti. L. \& Johnson. G. D. (eds). Interrelationships of Fishes: 445-479. Academic Press. London.

Cloutier, R. \& Schultze. H.-P. 1996. Porolepiform fishes (Sarcopterygii). In Schultze. H.-P \& Cloutier. R. (eds). Devonian Fishes and Plants of Miguasha. Quebec. Canada: 248-270. Verlag Dr. Friedrich Pfeil. München.

Cope, E. D. 1871. Observations on the systematic relations of the fishes. - American Naturalist 5: 579-593.

1889. Synopsis of the families of Vertebrata. - American Naturalist 23: 849 - 877

Denison. R. H. 1951. Late Devonian fresh-water fishes from the Western United States. - Fieldiana: Geology 11: $221-261$
1968. Early Devonian lungfishes from Wyoming, Utah and Idaho. - Fieldiana: Geology 17: 353-413.

Dennis. K. \& Miles, R. S. 1981. A pachyosteomorph arthrodire from Gogo. Western Australia. - Zoological Journal of the Linnean Society 73: $213-258$.

Forev. P. J. 1981. The coelacanth Rhabdoderma in the Carboniferous of the British Isles. - Palaeontology 24: $203-229$

Fox. R. C.. Campbell. K. S. W., Barwick, R. E. \& Long, J. A. 1995. A new osteolepiform fish from the Lower Carboniferous Raymond Formation, Drummond Basin, Queensland. - Memoirs of the Queensland Museum 38: 97-223.

Gardiner. B. G. 1984. The relationships of the palaeoniscid fishes. a review based on new specimens of Mimia and Movthomasia from the Upper Devonian of Western Australia. - Bulletin of the British Museum (Natural History) 37: $173-428$.

Gardiner. B. G. \& Bartram, A. W. H. 1977. The homologies of ventral cranial fissures in osteichthyans. In Andrews, S. M.. Miles. R. S.. \& Walker, A. D. (eds). Problems in Vertebrate Evolution: 227-245, Academic Press, London.

Goujet. D. 1984. Les Poissons Placoderms du Spitsberg: Arthrodire Dolichothoraci de la Formation de Wood Bay (Dévonien inférieur). - Centre National de la Recherche Scientifique. Cahiers Paléontologie (Vértébres), Paris, 284pp.

Gross. W. 1933a. Die Fische des baltischen Devons. - Palaeontographica A 79: 1-74

- 1933b. Die Wirbeltiere des rheinischen Devons. 2. - Abhandlungen der Preussischen Geologischen Landesanstalt 154: $1-83$.

- 1941. Über den Unterkiefer einiger devonischer Crossopterygier. - Abhandlungen der Preussischen Akademie der Wissenschaften. Mathematisch-naturwissenschaftliche Klasse 20: 1-515.

- 1956. Über Crossopterygier und Dipnoer aus dem baltischen Oberdevon im Zusammenhang einer vergleichenden Untersuchung des Porenkanalsystems paläozoischer Agnathen und Fische. - Kungliga Svenska Vetenskaps Akademiens Handlingar 6: 5-140.

- 1966. Kleine Schuppenkunde. - Neues Jahrbuch für Geologie und Paläontologie. Abhandlungen 125: 29-48.

Janvier. P. 1980. Osteolepid remains from the Devonian of the Middle East. with particular references to the endoskeletal shoulder girdle. In Panchen. A. L. (ed.). The Terrestrial Environment and the Origin of Land Vertebrates. Systematics Association Special Volume 15; 223-254, Academic Press. London.

- 1996. Early Vertebrates. - Oxford Monographs on Geology and Geophysics 33. 393 pp. Oxford Science Publications. Clarendon Press, Oxford.

Jarvik. E. 1942. On the structure of the snout of crossopterygians and lower gnathostomes in general. - Zoologiska bidrag från Uppsala 21: $235-75$.

- 1948. On the morphology and taxonomy of the Middle Devonian osteolepid fishes of Scotland. - Kungliga Svenska VetenskapsAkademiens Handlingar (3. Serien) 25: $1-301$.

- 1950a. On some osteolepiform crossopterygians from the Upper Old Red Sandstone of Scotland. - Kungliga Svenska VetenskapsAkademiens Handlingar (4. Serien) 2: $1-35$.

- 1950b. Middle Devonian vertebrates from Canning Land and Wegeners Halvö (East Greenland). - Meddelelser om Grønland 96: 1-132.

- 1952. On the fish-like tail in the ichthyostegid stegocephalians. - Meddelelser om Grønland 114: 1-90.

- 1972. Middle and Upper Devonian Porolepiformes from East Greenland with special reference to Glyptolepis groenlandica n. sp. - Meddelelser om Grønland 187: $1-307$.

- 1980. Basic Structure and Evolution of Vertebrates. Volume 1: 575 pp.. Academic Press, London, New York 
- 1985. Devonian osteolepiform fishes from East Greenland. - Meddelelser om Grønland, Geoscience 13: 1-52.

Jessen, H. 1975. A new choanate fish, Powichthys thorsteinssoni n.g., n.sp., from the early Lower Devonian of the Canadian Arctic Archipelago. - Colloques International Centre National de Recherche 218: 214-222.

- 1980. Lower Devonian Porolepiformes from the Canadian Arctic with special reference to Powichthys thorsteinssoni Jessen. - Palaeontographica A 167: 180-214.

Johanson, Z. 1997a. New antiarchs (Placodermi) from the Hunter Siltstone (Famennian) near Grenfell, N.S.W. Alcheringa 21: $191-217$.

- 1997b. New Remigolepis (Placodermi; Antiarchi), from Canowindra, NSW, Australia. - Geological Magazine 134: 813-846.

Johanson, Z. \& Ahlberg, P. E. 1997. A new tristichopterid (Osteolepiformes: Sarcopterygii) from the Mandagery Sandstone (Late Devonian, Famennian) near Canowindra, NSW, Australia. - Transactions of the Royal Society of Edinburgh: Earth Sciences 88: 39-68.

- 1998. A complete primitive rhizodont from Australia. Nature 394: $569-573$

Johanson, Z. \& Ritchie, A. 2000. A new late Famennian lungfish from New South Wales, Australia, and its bearing on Australian/Asian terrane relations. - Alcheringa 24: 99-118.

Karatajūté-Talimaa, V. 1963. Genus Asterolepis from the Devonian of the Russian Platform. In Grigelis, A. \& Karatajūté-Talimaa, V. (eds). The Data on Geology of Lithuania: 65-223, Geological and Geographical Institute of the Academy of Science of Lithuania SSR, Vilnius. [In Russian with Lithuanian and English summaries].

Lebedev, O. 1992. The latest Devonian, Khovanian vertebrate assemblage of Andreyevka-2 locality, Tula Region, Russia. In Mark-Kurik, E. (ed.), Fossil Fishes as Living Animals, Academia 1: 265-272, Academy of Sciences of Estonia, Tallinn.

- 1995. A new osteolepid fish from Russia. - Bulletin du Muséum national d'Histoire naturelle, Paris (4 série) $\mathbf{1 7}$ (section C: Sciences de la Terre): 287-341.

Lehman, J.-P. 1959. Les Dipneustes du Dévonien supérieur du Groenland. -Meddelelser om Grønland 160: 1-58.

Li Zhengxiang, Powell, C. McA. \& Trench, A. 1993. Palaeozoic global reconstructions. In Long, J. A. (ed.). Palaeozoic Vertebrate Biostratigraphy and Biogeography: 25-53, Belhaven Press, London.

Liu Tungsen \& Pan Kiang 1958. Devonian fishes from Wutung Series near Nanking, China. - Palaeontologica Sinica 141: 1-41. [In Chinese with English summary].

Long, J. A. 1985a. The structure and relationships of a new osteolepiform fish from the Late Devonian of Victoria, Australia. - Alcheringa 9: 1-22.

- 1985b. A new osteolepidid fish from the Upper Devonian Gogo Formation, Western Australia. - Records of the Western Australian Museum 12: 361-377.

- 1989. A new rhizodontiform fish from the Early Carboniferous of Victoria, Australia, with remarks on the phylogenetic position of the group. - Journal of Vertebrate Paleontology 9: 1-17.

- 1991. The long history of Australian fossil fishes. In Vickers-Rich, P., Monaghan, J. M., Baird, R. F. \& Rich, T. H. (eds). Vertebrate Palaeontology of Australia: 336-428, Monash University Publication Committee, Melbourne.

- 1999. A new genus of fossil coelacanth (Osteichthyes: Coelacanthiformes) from the Middle Devonian of southeastern Australia. - Records of the Western Australian Museum Supplement 57: 37-54.

Long, J. A, Barwick, R. E. \& Campbell, K. S. W. 1997. Osteology and functional morphology of the osteolepiform fish Gogonasus andrewsi Long, 1985, from the Upper Devonian Gogo Formation, Western Australia. Records of the Western Australian Museum, Supplement 53: $1-89$.
M'Coy, F. 1848. On some new ichthyolites from the Scotch Old Red Sandstone. - Annals and Magazine of Natural History 2: 297-312.

Mark-Kurik, E. 1991. On the environment of Devonian fishes. - Proceedings of the Estonian Academy of Sciences, Geology 40: 122-125.

Metcalfe, I. 1996. Gonwanaland dispersion, Asian accretion and evolution of eastern Tethys. - Australian Journal of Earth Sciences 43: 605-634.

Miles, R. S. \& Westoll, T. S. 1968. The placoderm fish Coccosteus cuspidatus Miller ex Agassiz from the middle Old Red Sandstone of Scotland. Part I. Descriptive morphology. - Transactions of the Royal Society of Edinburgh 67: $373-476$

Murchison, R. I. 1839. The Silurian System. 768 pp., John Murray, London.

Ørvig, T. 1957. Remarks on the vertebrate fauna of the Lower Upper Devonian Escuminac Bay, P.Q, Canada, with special reference to the porolepiform crossopterygians. Arkiv för Zoologi 2: 367-426.

Owen, R. 1840. Odontography. Part 1. 655 pp., Hippolyte Bailliere, London.

- 1860. Palaeontology, or a Systematic Summary of Extinct Animals and their Geological Relations. 420 pp., Black, Edinburgh.

Pan Kiang 1956. On the Palaeozoic stratigraphy of the Nanking Hills. - Scientia Sinica 5: 543-559.

- 1957a. Chinese Devonian fish fossils and their stratigraphic and geographic distributions. - Collected Papers of Basic Data of Chinese Geology 1: 23-34. [In Chinese].

- 1957b. The correlations and age of the Wutung Series of the Lower Yangtze Valley and with a special discussion of the first discovery of Devonian Asterolepis in China. Acta Geologica Sinica 37: 455-473 34. [In Chinese with English summary]

- 1964. Some Devonian and Carboniferous fishes from South China. - Acta Palaeontologica Sinica 12: 139-168. [In Chinese with English summary].

Pan Kiang, Huo Fucher, Cao Jinqxuan, Gu Qichang, Liu Shiyu, Wang Junqing, Gao Lianda \& Liu Chun 1987. Continental Devonian System of Ningxia and its Biotas: 237 pp. Geological Publishing House, Beijing. [In Chinese with English summary].

Rich, T. H. \& Young, G. C. 1996. Vertebrate biogeographic evidence for connections of the east and southeast Asian blocks with Gondwana. - Australian Journal of Earth Sciences 43: 625-634.

Ritchie, A., Wang Shitao, Young, G. C. \& Zhang Guorui 1992. The Sinolepidae, a family of antiarchs (placoderm fishes) from the Devonian of South China and Eastern Australia. - Records of the Australian Museum 44: 319-370.

Romer, A. S. 1955. Herpetichthyes, Amphibioidei, Choanichthyes or Sarcopterygii? - Nature 176: 216.

Schmitz, B., Åberg, G., Werdelin, L., Forey, P. \& BendixAlmgreen, S. $1991 .{ }^{87} \mathrm{Sr} /{ }^{86} \mathrm{Sr}, \mathrm{Na}, \mathrm{F}, \mathrm{Sr}$ and $\mathrm{La}$ in skeletal fish debris as a measure of the paleosalinity of fossil-fish habitats. - Geological Society of America Bulletin 103: $786-794$.

Schultze, H.-P. 1973. Crossopterygier mit heterozerker Schwanzflosse aus dem Oberdevon Kanadas, nebst einer Beschreibung von Onchodontida-Resten aus dem Mitteldevon Spaniens und aus dem Karbon der USA. - Palaeontographica A 143: 188-208.

Schultze, H.-P. \& Arsenault, M. 1987. Quebecius quebecensis (Whiteaves), a porolepiform crossopterygian (Pisces) from the Late Devonian of Quebec, Canada. - Canadian Journal of Earth Sciences 24: 2351-2361.

Schultze, H.-P. \& Chorn, J. 1998. Sarcopterygian and other fishes from the marine Upper Devonian of Colorado, U.S.A. - Mitteilungen aus dem Museum für Naturkunde in Berlin, Geowissenschaftliche Reihe 1: 53-72. 
Stensiö, E. A. 1922. Über zwei Coelacanthiden aus dem Overdevon von Wildungen. - Palaeontologische Zeitschrift 4: $167-210$.

Thomson. K. S. 1968. A new Devonian fish (Crossoptervgii: Rhipidistia) considered in relation to the origin of the Amphibia. - Postilla 24: 1-13.

- 1973. Observations on a new rhipidistian fish from the Late Devonian of Australia. - Palaeontographica A 143 $209-220$.

Thomson. K. S. \& Rackoff. J. S. 1974. The shoulder girdle of the Permian rhipidistian fish Ectosteorhachis nitidus Cope: Structure and possible function. - Journal of Paleontology 48: 170-179.

Traquair. R. H. 1888. Notes on the nomenclature of the fishes of the Old Red Sandstone of Great Britain. - Geological Magazine 5: 507-517.

Vorobveva. E. I. 1959. A new genus of crossopterygian fish - Platycephalichthys from the Upper Devonian of Lovat. - Paleontogicheskii Zhurnal Akademiva Nauk SSSR 3: 95-106. [In Russian].

- 1977. Morfologiya $\mathrm{i}$ osobennosti evolyutsii kistepervkh ryb. - Trudy Paleontologicheskogo Instituta. Akademiya Nauk SSSR 94: 1-139. [In Russian].

- 1980. Observations on two rhipidistian fishes from the Upper Devonian of Lode. Latvia. - Zoological Journal of the Linnean Society 70: 191-201.

Vorobyeva. E. I. \& Schultze. H.-P. 1991. Description and systematics of Panderichthyid fishes with comments on their relationship to tetrapods. In Schultze. H.-P. \& Trueb. L. (eds). Origins of the Higher Groups of Tetrapods. Controversy and Consensus: 68-109. Comstock. Ithaca

Wang Junqing 1984. Geological and Palaeogeographica Distribution of Devonian fishes in China. - Vertebrata PalAsiatica 22: 219-229.

Wang Shitao 1993. Vertebrate biostratigraphy of the middle Palaeozoic of China. In Long. J. A. (ed.). Palaeozoic Vertebrate Biostratigraphy and Biogeography: 252-275. Belhaven Press. London.

Whiteaves. J. F. 1881. On some remarkable fossil fishes from the Devonian rocks of Scaumenac Bay. Province of Quebec, with descriptions of a new genus and three new species. - Canadian Naturalist 10: $27-35$.
Woodward. A. S. 1891. Catalogue of the Fossil fishes in the British Museum (Natural History). Part II. 567 pp., London.

Yang Shihpu. Pan Kiang \& Hou Hungfei. 1981. The Devonian system in China. - Geological Magazine 118: $113-138$.

Young, G. C. 1988. Antiarchs (placoderm fishes) from the Devonian Aztec sandstone, southern Victoria Land, Antarctica. - Palaeontographica A 202: 1-125.

- 1993. Middle Palaeozoic macrovertebrate biostratigraphy of Eastern Gondwana. In Long, J. A. (ed.). Palaeozoic Vertebrate Biostratigraphy and Biogeography: 208-251, Belhaven Press, London.

- 1999. Preliminary report on the biostratigraphy of new placoderm discoveries in the Hervey Group (Upper Devonian) of central New South Wales. - Records of the Western Australian Museum, Supplement 57: $139-150$.

Young. G. C. \& Janvier. P. 1999. Early-middle Palaeozoic vertebrate faunas in relation to Gondwana dispersion and Asian accretion. In Metcalfe, I. (ed.). Gondwana Dispersion and Asian Accretion, IGCP 321 Final Results Volume: 115-140. A. A. Balkema, Rotterdam.

Young. G. C.. Long. J. A. \& Ritchie, A. 1992. Crossopterygian fishes from the Devonian of Antarctica: Systematics, relationships and biogeographic significance. - Records of the Australian Museum, Supplement 14: 1-77.

Young. J. 1866. Notes of new genera of Carboniferous glyptodipterines. - Quarterly Journal of the Geological Society 22: $596-608$

Yu Xiaobo 1998. A new porolepiform-like fish, Psarolepis romeri gen et sp. nov. (Sarcopterygii, Osteichthyes) from the Lower Devonian of China. - Journal of Vertebrate Paleontology 18: 261-279.

Zhao XiXi, Coe. R. S., Gilder, S. A. \& Frost, G. M. 1996. Palaeomagnetic constraints on the palaeogeography of China: implications for Gondwanaland. - Australian Journal of Earth Sciences 43: 643-672.

Zhu Min. Yu Xiaobo \& Janvier, P. 1999. A primitive fossil fish sheds light on the origin of bony fishes - Nature 397: $607-612$. 